\title{
Development of a Haddon Matrix Framework for Higher Education Pandemic Preparedness: Scoping Review and Experiences of Malaysian Universities During the COVID-19 Pandemic
}

Mohd Shahir Shamsir ${ }^{\mathrm{a}}$, Steven Eric Krauss ${ }^{\mathrm{b}}$ (1), Ismi Arif Ismail ${ }^{\mathrm{b}}$, Habibah Ab Jalil ${ }^{\mathrm{b}}$, Muhammad Akmal Johar ${ }^{\mathrm{c}}$ and

Ismail Abdul Rahman ${ }^{\mathrm{d}}$

${ }^{a}$ Faculty of Applied Sciences and Technology, Universiti Tun Hussein Onn Malaysia, Pagoh Higher Education Hub, 84600 Muar, Johor, Malaysia.

${ }^{\mathrm{b}}$ Innovative Learning Sciences Research Centre of Excellence (INNOVATE), Faculty of Educational Studies, Universiti Putra Malaysia, 43400 Serdang, Selangor, Malaysia.

E-mail: lateef@upm.edu.my

${ }^{c}$ Faculty of Mechanical and Manufacturing Engineering, Universiti Tun Hussein Onn Malaysia, 86400 Batu Pahat, Johor, Malaysia.

${ }^{\mathrm{d}}$ Faculty of Civil Engineering and Built Environment, Universiti Tun Hussein Onn Malaysia, 86400 Batu Pahat, Johor, Malaysia.

Managing education and research during pandemics has increased in importance since the onset of epidemics such as avian flu, SARS and now CoViD-19. Successful management in times of crisis ensures business continuity and institutional survival, making preparedness preceding an impending pandemic essential. Institutions of higher education (IHEs) must maintain balance between academic continuity and preventing morbidity during a pandemic crisis. To date, however, no general pandemic preparedness frameworks exist for IHEs. The aim of this paper is to report on the development of a Haddon matrix framework for IHE pandemic preparedness based on a scoping literature review of past IHE responses including pre-, during and post-pandemic phases. First, a review of previous global responses by IHEs during past pandemics was carried out. The review findings were then collated into a new IHE-centric Haddon matrix for pandemic preparedness. The content of the matrix is then illustrated through the documented responses of Malaysian universities during the early stages of the COVID-19 pandemic. The resulting IHE Haddon matrix can be used by universities as a general guide to identify preparedness gaps and intervention opportunities for business continuity during pandemics.

Higher Education Policy (2022) 35, 439-478. https://doi.org/10.1057/s41307-02000221-x; published online 14 January 2021 
Mohd Shahir Shamsir et al.

Development of a Haddon Matrix Framework

440

\section{Introduction}

On 31 December 2019, a novel coronavirus was reported to the World Health Organization (WHO) in China. The disease was subsequently named the Coronavirus disease 2019 (COVID-19) in February of 2020. Considered possibly as a "Once-in-a-Century" pandemic with a case fatality risk half of the Spanish flu (Gates, 2020), it poses a greater threat due to its ability to be transmitted by individuals who are not symptomatic (Hoehl et al., 2020). By late March 2020, there were more than 90,000 reported cases worldwide and more than 3000 reported deaths globally making the COVID-19 fatality rate 3.4 percent (Ghebreyesus, 2020). It was expected that these numbers would increase substantially as cases in Europe had yet to be accounted for.

The emergence of past epidemics from viral diseases causing anthropogenic and societal disruptions has raised the issue of business continuity for institutions of higher education (IHE). Many epidemics of emerging or re-emerging viral diseases over the past two decades should have increased the readiness level of IHEs in dealing with pandemics (Reperant and Osterhaus, 2017; Ryu, 2017). A large, cautionary literature on the dangers of potential viral diseases has been in print for over 30 years (Culliton, 1990; Gates, 2015; Morse and Schluederberg, 1990). In response to the challenges created by these re-occurring infectious diseases, especially emerging zoonotic diseases (Taylor et al., 2001), the subject of business continuity and pandemic planning has been raised by both the public and private sectors. These threats have forced entities to plan suitable responses to preserve operational integrity and future existence. Therefore, similar responses should be readily available by IHEs in order to maintain their operational continuity in respect to providing educational services to their students and other stakeholders. Failure to respond adequately can disrupt IHE operations and compromise longterm functionality and viability as well as affect institutional credibility within the learning community. In the context of IHEs, crises such as viral pandemics pose a high risk to the university ecosystem. IHEs are comprised of many people in close contact with one another, facilitating the rapid spread of an infectious agent. On the other hand, IHEs possess a large reservoir of energy and talent in the form of students and academicians that if mobilized correctly, can contribute to risk management during a pandemic (Wang et al., 2020).

The lack of clear planning frameworks and strategies for pandemic preparedness by IHEs has been exposed as a result of the COVID-19 pandemic. COVID-19 has dramatically altered the functioning of IHEs across the globe including reductions in international education, disruption to the academic calendar, cancellation of local and international conferences, teaching and learning gaps, workforce cuts and cuts in higher education budgets (Jacob et al., 2020; Marinoni et al., 2020). Among these disruptions, foremost has been the shift to teaching and learning in an online environment. Much of the IHE-related literature on COVID-19 responses has 
Mohd Shahir Shamsir et al.

reported on the experiences and challenges in shifting to online learning and online pedagogies (Adnan and Anwar, 2020; Dhawan, 2020; Rapanta et al., 2020; Shenoy et al., 2020). In their review of 20 countries' digital pedagogy responses to COVID19, Crawford et al. (2020) found a wide range of responses by universities in different countries, from the implementation of very minimum measures (e.g. 1.5$\mathrm{m}$ distance or reduced social gatherings) to the full closure of face-to-face operations and migration to digitalized education. Some universities were already partially prepared for the pandemic given their existing blended or fully online offerings. Outside of teaching and learning, few studies report on university management responses and planning for future pandemics as a result of COVID-19. One exception is a study by Wang et al. (2020), who reported on risk management efforts made by Chinese universities at the early stages of the COVID-19 epidemic. In their response to the pandemic, Chinese universities have emphasized resource collection from alumni, medical rescue and emergency management, mental health maintenance, control of staff mobility and innovation in online education models. To date, no known studies have reported on the use of the Haddon Matrix in an IHE context for COVID-19 pandemic response planning.

The aim of this paper is to report on the development of a tool for IHE pandemic preparedness based on a probing literature review of past IHE responses. First, a review of previous global responses by IHEs during past pandemics was carried out. Second, the review findings were collated into a Haddon matrix. The Haddon matrix has been used to study preparedness against viral outbreaks such as Severe Acute Respiratory Syndrome (SARS) (Barnett et al., 2005a), flu (Barnett et al., 2005b) and Ebola (Phua, 2015). Scenarios in which the Haddon matrix has been used are limited, however, to preparedness for health authorities only. To date, no pandemic preparedness matrix has been developed for IHEs. By combining the features of the original Haddon matrix used for public health institutions with the findings from the scoping review, a new, IHE-centric Haddon matrix for pandemic preparedness was developed. Finally, drawing on literature and observational data of recorded administrative responses to the COVID-19 outbreak by IHEs in Malaysia, we discuss the application of the new IHE-centric matrix framework within the context of Malaysian IHE responses to COVID-19. The proposed matrix is intended to be used in the future by universities as a general guide to identify preparedness gaps and intervention opportunities for business continuity during pandemics.

\section{Institutions of higher education and pandemic preparation: applicability of the Haddon matrix}

Scientific literature on disaster management tends to proliferate following the occurrence of an epidemic. Examination of the disaster literature landscape using the Lens Database (https://www.lens.org/) from the past 30 years shows that the 
Mohd Shahir Shamsir et al.

Development of a Haddon Matrix Framework

442

number of studies published in scientific journals on flu preparedness surged after every major outbreak (Figure 1) (unpublished data). Thus, an ample amount of scientific material is available to formulate proper responses for IHEs in regard to a global pandemic. In order to better understand the challenges facing IHEs as a result of the CoViD-19 pandemic, the preparedness problem is broken down into the dimensions of time and contributing factors. Responses extracted from the literature on past IHE practices during pandemics can then be mapped into a Haddon matrix.

The Haddon matrix is a public safety model that was developed in the field of injury prevention to reduce morbidity and mortality by standardising safety analysis (Haddon, 1968). The matrix is a two-dimensional grid with four columns and three rows. The first domain of the model involves rows that are divided to represent different phases of an injury [pre-event, event and post-event]. The second domain is known as influencing factors [host, agent/vector, physical environment, social environment] (Table 1). It was the starting analytical matrix for the 2004-2006 World Health Organization (WHO) and Centers for Disease Control's (CDC) Pandemic Influenza Preparedness Plan until the matrix was expanded to the current six phase framework (Holloway et al., 2014).

Separating a problem into its dimensions of time and contributing factors, the matrix can be utilized as a practical, user-friendly interdisciplinary planning tool to help understand, prepare for and respond to a broad range of public health emergencies (Runyan, 2003). Ever since the Haddon matrix has been adopted from the use of injury prevention to the field of public health readiness and response planning, it has been used to analyse preparedness for diseases such as cholera (Anparasan and Lejeune, 2017), streptococcicosis (Ye-hua, 2006), bioterrorism pathogens (Pappas et al., 2009) and even unique emergencies or disasters such as terrorism (e.g. bombing [Arnold, 2005; Yan and Yu, 2019]), hurricanes (Rogers and Lawhorn, 2007) and sarin attacks (Varney et al., 2006). The scalability of the Haddon Matrix makes it suitable for studying the preparedness of institutions affected by diseases such as nations (Thailand, Israel) (Barnett et al., 2005b), childcare centres (Teng-teng, 2015; Townley and McKnight, 1994), outdoor music festivals (Hutton et al., 2015), industries (e.g. mining (Engström et al., 2018)), agriculture (Rautiainen et al., 2008) and location (e.g. rural or urban settings [Cheng and $\mathrm{Xu}, 2008])$.

\section{Methodology}

\section{Study context}

On 16 March 2020, the government of Malaysia announced the nationwide implementation of a 14-day Movement Control Order (MCO) from 18th of March to 31st of March 2020 to control the spread of COVID-19. At the onset, Malaysian 
Mohd Shahir Shamsir et al.

Development of a Haddon Matrix Framework

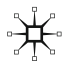

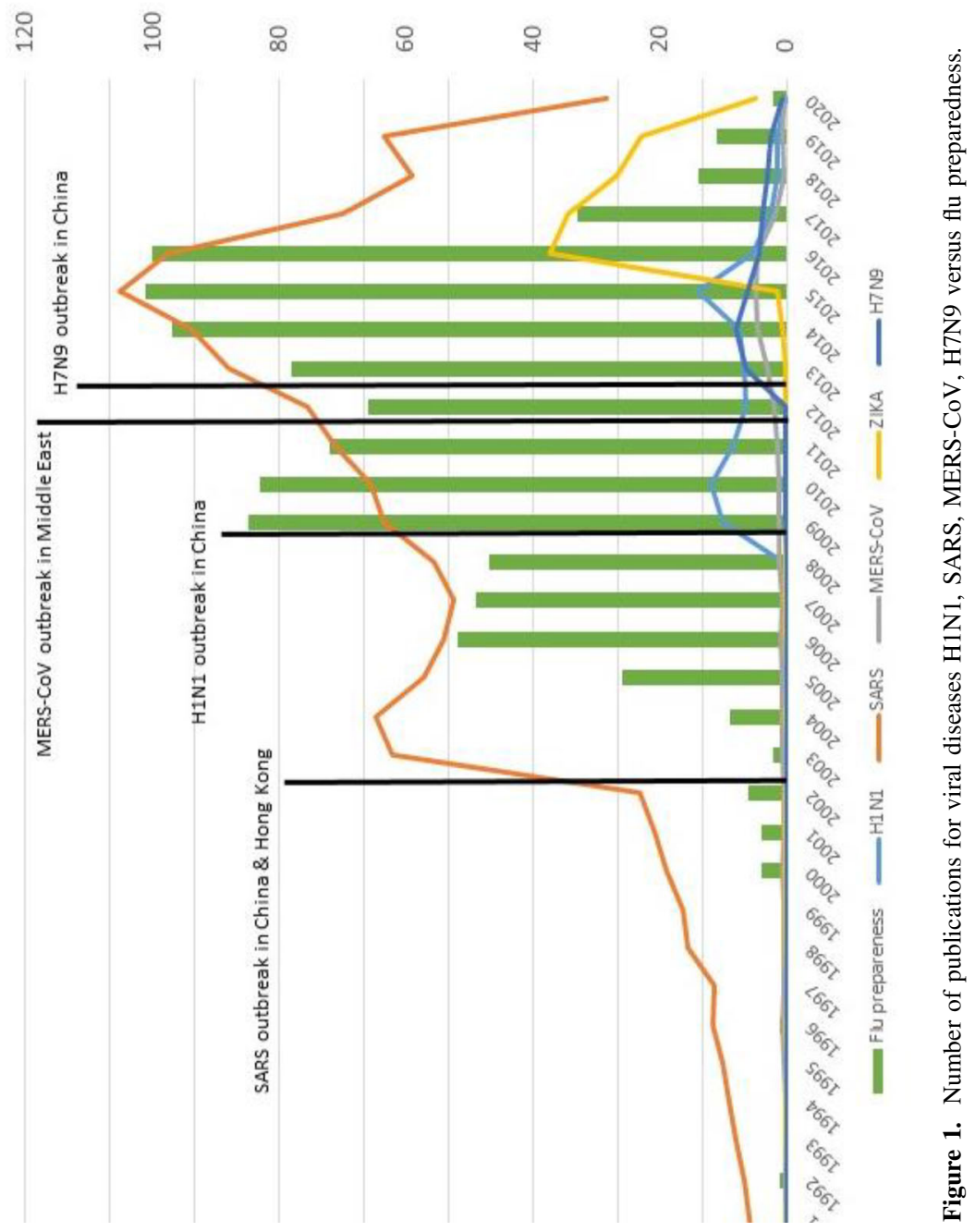

Higher Education Policy 202235 
Mohd Shahir Shamsir et al.

Development of a Haddon Matrix Framework

444

Table 1 The use of the Haddon matrix as an analytic and planning tool for pandemic influenza [simplified from Barnett et al. (2005a, b)]

\begin{tabular}{|c|c|c|c|c|}
\hline Phase & Human factors & Agent/vector & $\begin{array}{l}\text { Physical } \\
\text { environment }\end{array}$ & $\begin{array}{l}\text { Sociocultural } \\
\text { environment }\end{array}$ \\
\hline $\begin{array}{l}\text { Pre- } \\
\text { event }\end{array}$ & $\begin{array}{l}\text { Surveillance for } \\
\text { influenza and } \\
\text { influenza-like } \\
\text { illness syndrome } \\
\text { Surveillance and } \\
\text { monitoring of } \\
\text { strains for genetic } \\
\text { and phenotypic } \\
\text { changes }\end{array}$ & $\begin{array}{l}\text { Genetic and phenotype } \\
\text { variation in virulence, } \\
\text { transmissibility, host range, } \\
\text { and antiviral susceptibility } \\
\text { Strain pathogenicity to } \\
\text { human hosts }\end{array}$ & $\begin{array}{l}\text { Hospital infection } \\
\text { control } \\
\text { infrastructure } \\
\text { Personal protective } \\
\text { equipment for } \\
\text { health care } \\
\text { personnel } \\
\text { Laboratory } \\
\text { facilities }\end{array}$ & $\begin{array}{l}\text { Public health } \\
\text { infrastructure } \\
\text { Infection } \\
\text { control } \\
\text { practices in } \\
\text { health care } \\
\text { settings }\end{array}$ \\
\hline Event & $\begin{array}{l}\text { Trained health care } \\
\text { and public health } \\
\text { personnel } \\
\text { Health care staff } \\
\text { adherence to } \\
\text { infection control } \\
\text { protocols }\end{array}$ & $\begin{array}{l}\text { Infectivity } \\
\text { Incubation period } \\
\text { Modes of transmission } \\
\text { Lethality }\end{array}$ & $\begin{array}{l}\text { Health care } \\
\text { infrastructure surge } \\
\text { capacity } \\
\text { Stockpiled } \\
\text { antivirals, } \\
\text { antibiotics and } \\
\text { personal } \\
\text { protective } \\
\text { equipment } \\
\text { Hospital infection } \\
\text { control } \\
\text { infrastructure }\end{array}$ & $\begin{array}{l}\text { Detailed } \\
\text { response plan } \\
\text { Criteria for } \\
\text { declaring a } \\
\text { state of } \\
\text { emergency } \\
\text { Public's } \\
\text { psychological } \\
\text { preparedness } \\
\text { Public trust in } \\
\text { government's } \\
\text { crisis } \\
\text { management }\end{array}$ \\
\hline $\begin{array}{l}\text { Post } \\
\text { event }\end{array}$ & $\begin{array}{l}\text { Post-event risk } \\
\text { communication } \\
\text { Psychology of post- } \\
\text { event reactions }\end{array}$ & $\begin{array}{l}\text { Persistence of agent in } \\
\text { environment } \\
\text { Genetic drifts }\end{array}$ & $\begin{array}{l}\text { Restoration of } \\
\text { medication stocks } \\
\text { and equipment }\end{array}$ & $\begin{array}{l}\text { Governmental } \\
\text { financial and } \\
\text { mental health } \\
\text { support } \\
\text { Economic } \\
\text { impact on } \\
\text { affected } \\
\text { community }\end{array}$ \\
\hline
\end{tabular}

universities made many proactive decisions including the full closure of campuses. During the early stages of the crisis, government instructions regarding the control and containment of the disease were limited to those from the District Health Office; there was no centralized governmental guidance on managing other aspects of the crisis such as continuity in teaching and learning, managing research, and the welfare of staff and students. Decisions made by many universities were done so on an individual basis by consensus of top management despite most universities having no prior experience in managing disasters of the magnitude of the COVID19 outbreak. Based on this first-hand experience, the authors were inspired to seek information from the scientific literature on the past experiences of IHEs in 
Mohd Shahir Shamsir et al.

response to disease outbreaks and pandemics. In so doing, the aim was to document the process and outcomes, which could be useful for other IHEs as a general guide for similar future emergency situations.

\section{Haddon matrix review}

We employed a scoping review of studies on the assessment, preparedness and response by IHEs during epidemics or related emergencies involving infectious diseases. Scoping reviews are often employed for reviewing studies related to disaster preparedness as they can be used to rapidly map the key preparedness points that are too differentiated and broad for a systematic review (Riccardo et al., 2018; Wilson et al., 2012a, b). Studies on disaster preparedness and response by IHEs span across multiple disciplines (e.g. management, education, disaster preparedness, legal) (Anparasan and Lejeune, 2017; Cole et al., 2020; Engström et al., 2018; Kakkar et al., 2010; Zhong et al., 2014). Although we did not employ meta-analysis, systematic review methods were utilized to minimize bias in the identification and inclusion of the studies (Daudt et al., 2013). The comprehensive literature search included the use of a combination of predetermined search criteria, as listed in Table 2. The review was performed during the first MCO period from the 18th of March to 31st of March 2020 using electronic databases Google Scholar (https://scholar.google.com/) and Google (https://www.google.com/). Google is the most comprehensive academic search engine with the largest coverage of literature found in academic search engines and bibliographic databases (ASEBDs), which include subscription-based SCOPUS and Web of Science databases (López-Cózar et al., 2019; Gusenbauer, 2019; Martin-Martin et al., 2017). The collected publications were collated using Mendeley Desktop software package version 1.19.4 (Mendeley Ltd, London, UK) to prevent duplications.

Resulting papers from the initial search were first assessed for relevance. During the initial screening phase, the papers were assessed based on their titles. Studies not relevant to the research topic were excluded. For example, the search protocol returned papers related to studies on the perception and knowledge of diseases among students in health-related fields. These were excluded since they are designed to assess students' level of knowledge of an ongoing epidemic as part of

Table 2 Predetermined search criteria used in the systematic literature review

\begin{tabular}{lll}
\hline Criteria & Search terms & Timeline criteria \\
\hline $\begin{array}{l}\text { Action taken by IHE } \\
\text { before, during and } \\
\text { after the pandemic }\end{array}$ & $\begin{array}{c}\text { outbreak "university students" - } \\
\text { obesity -tobacco -HIV -sexual - }\end{array}$ & $\begin{array}{c}\text { 1996-2020 in accordance with } \\
\text { epidemic responses recorded by }\end{array}$ \\
event & "medical students" - "nursing & WHO (https://www.who.int/csr/ \\
& Students" awareness, MERS, flu, & don/archive/year/en/) \\
& SARS & \\
\hline
\end{tabular}


Mohd Shahir Shamsir et al.

Development of a Haddon Matrix Framework

446

their coursework. In the second phase, abstracts of each paper were assessed for specific inclusion and exclusion criteria. Studies were included if they met any of the following three criteria: (1) the aim was to identify action taken by an affected IHE before, during and after the pandemic event; (2) human, physical and sociocultural factors were discussed; (3) the abstract was written in English. Papers were excluded due to the following reasons: (1) papers published in different journals that contained near identical content (e.g., journal and conference submissions on the same topic); (2) theoretical assessments of pandemic factors not directly related to IHE (e.g., thought experiments); (3) studies based on surveys with members of the public other than IHE staff or student populations; or (4) if IHE staff and students comprised only a portion of the overall sample of respondents. The date of the study was used in the timeline rather than the date of publication as studies may be published significantly later than the actual completion of the study due to lengthy editorial processes.

The factors associated with IHE were identified in each phase (pre-event, event, post-event) and on each axis (human, agent/vector, physical environment, sociocultural environment) and were added into the new IHE matrix. We then identified factors that may be associated with opportunities for IHE intervention, and marked these factors in bold within the matrix, as described by Runyan (2003). The factors were then compared with responses from Malaysian IHE management during the MCO period of the COVID-19 pandemic. Each phase of the pandemic presents a unique set of demands on IHEs in their preparedness and response efforts.

\section{Results and Discussion}

\section{Systematic review of IHE responses to past pandemics}

The selected search terms produced an initial 30,100 results, which were then reduced by adding exclusion keywords and specific diseases. The selection of "flu", "MERS" and "H1N1" were used as final criteria to limit the results to virusrelated studies. A final 42 published studies were identified from the literature search, and qualified studies were tabulated in an ascending timeline according to country, time of the epidemic, type of disease, sample, recommendations for planning and preparedness in administrative, teaching, research and student affairs, and the study citation (see "Appendix" for full list of studies) (See Figure 2 for selection process).

From the studies selected, recommendations for planning and preparedness were categorized into four main types: administrative, teaching, research and student affairs. Majority of the recommendations focused on welfare of students (76\%), followed by recommendations for IHE administrators (40\%), recommendations for teaching $(7 \%)$ and research $(5 \%)$. IHEs that were affected by an outbreak on their 
Mohd Shahir Shamsir et al.

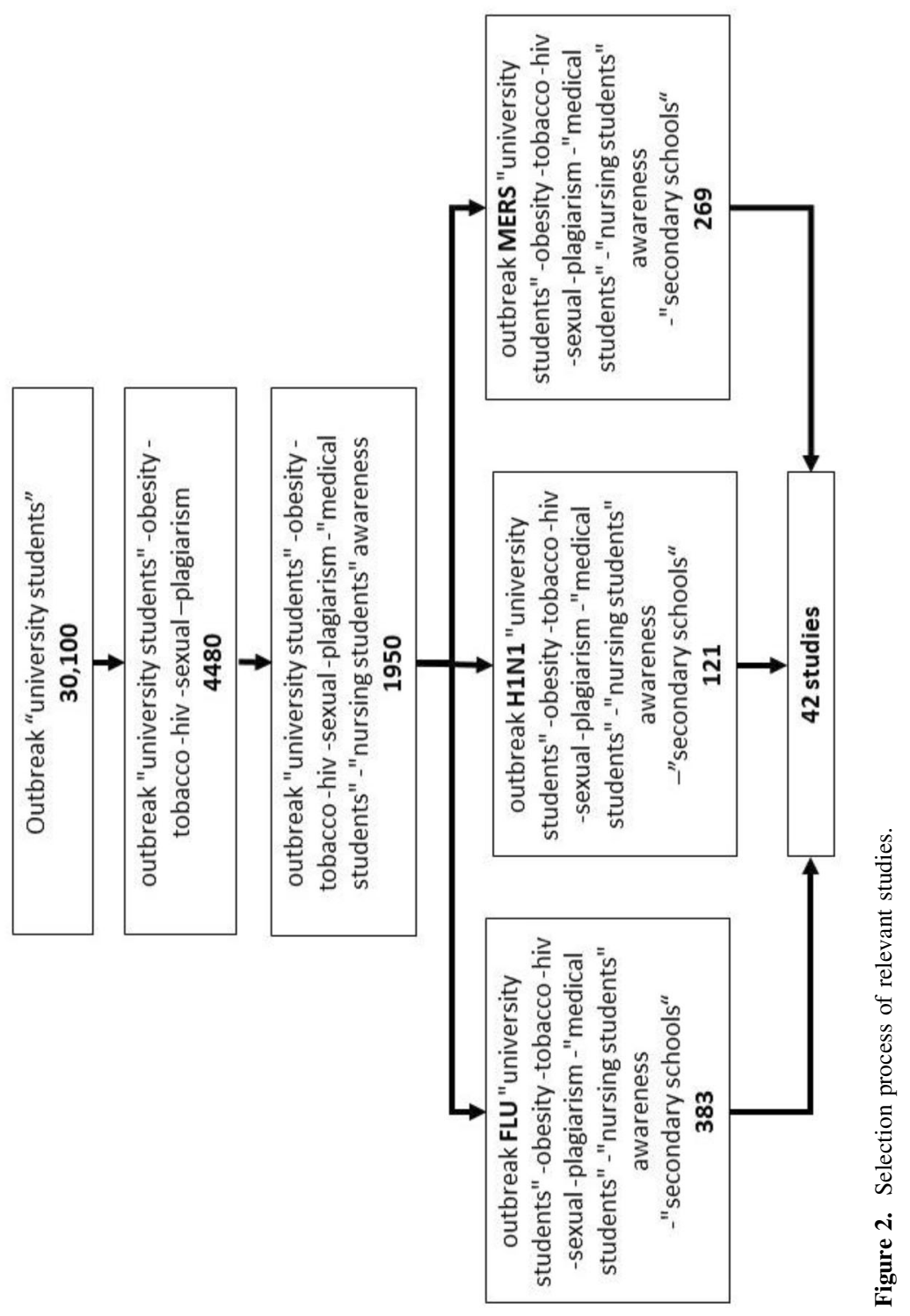


Mohd Shahir Shamsir et al.

Development of a Haddon Matrix Framework

448

own campuses (italic rows) accounted for the highest number of recommendations for student welfare. Only three studies recommended switching to distance or online learning, beginning with the 2009-2010 H1N1 outbreak. In their tabletop exercise for flu pandemic planning in 2007, University of Washington administrators recommended the need to reduce the presence of on-site staff through distance learning modalities (Beaton et al., 2007). In their study of staff and student responses to the H1N1 pandemic in Australia, Van et al. (2010) found little use of, and support for, online teaching or learning resources as a result of the pandemic despite student willingness to do so. The authors recommended university support for technologies that allow faculty and students to continue their teaching and learning activities to minimize disruption.

Several studies cited administrative recommendations for pandemic planning. Sixteen of the forty-two studies identified cited administrative recommendations, which included the need for centralized campus operation centres (Beaton et al., 2007); awareness and information dissemination (Salman et al., 2017; Park et al., 2016; Etokidem et al., 2018); the use of electronic and ICT tools for enhancing communication to staff and students (Seale et al., 2011; Ekmekci and Bergstrand, 2010); emphasis on emergency preparedness procedures such as preplanning, and mitigation efforts (Coveleski, 2014; Araz et al., 2011), avoiding oversaturation of information (Koskan et al., 2012; Mitchell et al., 2014), and closing campuses and implementing necessary interventions when deemed necessary (Park et al., 2016; Virk et al., 2017).

Planning and preparation for student affairs centred around the need to have adequate support services for students and staff experiencing anxiety, stress, depression and other mental disorders resulting from pandemics (Wong et al., 2004, 2007; Cheng and Cheung, 2005). Another major area of student affairs planning and preparation included dealing with international and summer school students, who may be stranded on campus during a pandemic outbreak (Beaton et al., 2007). Several papers discussed the need for critical strategies for communicating the importance of adopting public health measures such as hand washing, mask use and avoiding touching the nose and mouth at times of a pandemic (Mitchell et al., 2011; Surgeoner et al., 2009; Gu et al., 2015). Research recommendations were almost completely absent, except for two recommendations on the upkeep and welfare of laboratory animals. The absence of recommendations in teaching and learning could be due to the smaller scale of past outbreaks as compared to the COVID-19 pandemic, the brief time period of past outbreaks and the context of the studies, which centred on only one or a few IHEs.

\section{Haddon matrix for future IHE pandemic preparedness}

Considering the findings from the systematic review, the Haddon matrix for IHE preparedness was populated and described (Table 3). The agent/vector axis was 
Mohd Shahir Shamsir et al.

Table 3 Haddon matrix for IHE preparedness and planning for flu pandemic

\begin{tabular}{|c|c|c|c|c|}
\hline Phase & Human factors & Agent/vector & Physical environment & $\begin{array}{l}\text { Sociocultural } \\
\text { environment }\end{array}$ \\
\hline $\begin{array}{l}\text { Pre- } \\
\text { event }\end{array}$ & $\begin{array}{l}\text { Readiness of the } \\
\text { student and staff } \\
\text { populations to work } \\
\text { remotely } \\
\text { Prioritization shift by } \\
\text { university } \\
\text { management } \\
\text { Formation of a crisis } \\
\text { management team }\end{array}$ & $\begin{array}{l}\text { Genetic and } \\
\text { phenotype } \\
\text { variation in } \\
\text { virulence, } \\
\text { transmissibility, } \\
\text { host range }\end{array}$ & $\begin{array}{l}\text { Readiness of IHE } \\
\text { medical support } \\
\text { facilities to test, identify } \\
\text { and process infected } \\
\text { individuals } \\
\text { Teaching and learning } \\
\text { materials designed for } \\
\text { distance learning } \\
\text { especially laboratory } \\
\text { or practical lessons }\end{array}$ & $\begin{array}{l}\text { Continuous disaster } \\
\text { drills, tabletop } \\
\text { exercises and } \\
\text { emergency training } \\
\text { Practicing online/ } \\
\text { distance learning } \\
\text { and assessment }\end{array}$ \\
\hline Event & $\begin{array}{l}\text { Trained staff deliver } \\
\text { teaching and learning } \\
\text { remotely } \\
\text { IT staff trained to } \\
\text { work remotely } \\
\text { Support staff } \\
\text { trained to work } \\
\text { off-campus or } \\
\text { work from home } \\
\text { Support staff to } \\
\text { support on- } \\
\text { campus } \\
\text { quarantined } \\
\text { students during } \\
\text { travel restrictions } \\
\text { International office } \\
\text { to assist expatriate } \\
\text { or repatriated staff } \\
\text { or students } \\
\text { Security to maintain } \\
\text { quarantine cordon }\end{array}$ & $\begin{array}{l}\text { Infectivity } \\
\text { Incubation period } \\
\text { Modes of } \\
\quad \text { transmission } \\
\text { Lethality }\end{array}$ & $\begin{array}{l}\text { Dedicated Crisis } \\
\text { Management Centre } \\
\text { (CMC) } \\
\text { IT infrastructure for } \\
\text { online learning } \\
\text { Delivery of materials } \\
\text { for distance learning } \\
\text { Access to campus } \\
\text { laboratory facilities } \\
\text { On-Campus } \\
\text { Quarantine facilities } \\
\text { Transportation services } \\
\text { to ferry students from } \\
\text { medical centres } \\
\text { Equipment for food } \\
\text { delivery and medical } \\
\text { surveillance } \\
\text { Decontamination } \\
\text { equipment } \\
\text { Laboratory } \\
\text { maintenance during } \\
\text { lockdown }\end{array}$ & $\begin{array}{l}\text { Detailed IHE } \\
\text { response plan } \\
\text { Students and staff } \\
\text { psychological } \\
\text { preparedness } \\
\text { Students' trust in } \\
\text { IHE crisis } \\
\text { management } \\
\text { Real-time reporting } \\
\text { of location, health } \\
\text { status for } \\
\text { tracking and data } \\
\text { collection } \\
\text { Communication } \\
\text { strategy } \\
\text { to allay anxiety of } \\
\text { students and staff } \\
\text { Communication } \\
\text { with companies } \\
\text { hosting practicum } \\
\text { students } \\
\text { Material support } \\
\text { by research teams } \\
\text { to boost morale } \\
\text { and create a } \\
\text { common goal }\end{array}$ \\
\hline
\end{tabular}


Mohd Shahir Shamsir et al.

Development of a Haddon Matrix Framework

450

Table 3 continued

\begin{tabular}{|c|c|c|c|c|}
\hline Phase & Human factors & Agent/vector & Physical environment & $\begin{array}{l}\text { Sociocultural } \\
\text { environment }\end{array}$ \\
\hline $\begin{array}{l}\text { Post } \\
\text { event }\end{array}$ & $\begin{array}{l}\text { Post-event risk } \\
\text { communication } \\
\text { Psychology of post- } \\
\text { event reactions } \\
\text { Post-event influenza- } \\
\text { like illness } \\
\text { surveillance }\end{array}$ & $\begin{array}{l}\text { Persistence of } \\
\text { agent in } \\
\text { Environment } \\
\text { Genetic drifts }\end{array}$ & $\begin{array}{l}\text { Screening and } \\
\text { quarantine facilities for } \\
\text { students entering } \\
\text { campus housing } \\
\text { Decontamination of } \\
\text { facilities }\end{array}$ & $\begin{array}{l}\text { Implementation of } \\
\text { "lessons learned" } \\
\text { Functionality of IHE } \\
\text { health care } \\
\text { Governmental } \\
\text { financial support } \\
\text { Mental health } \\
\text { support for staff } \\
\text { and students }\end{array}$ \\
\hline
\end{tabular}

Major content [plain text, bold italic] is taken from Barnett et al. (2005a, b)], preparedness recommended by past IHEs [italic] and preparedness learned from Malaysian IHE experiences [bold]).

identical to previous Haddon matrices describing preparedness against viral infectious agents such as cholera (Anparasan and Lejeune, 2017), Severe Acute Respiratory Syndrome (SARS) (Barnett et al., 2005a), flu (Barnett et al., 2005b) or Ebola (Phua, 2015), and the cells were left plain white.

The development of the new IHE Haddon matrix was performed in three steps. The first step relied on the original Haddon matrix created for flu outbreak preparedness to populate the cells. Each relevant factor in each phase (pre-event, event, post-event) and on each axis (human, agent/vector, physical environment, sociocultural environment) from the original Haddon matrix was added into the matrix. The human factors column refers to staff and students of the IHE. It excludes any individuals not under the direct purview of the IHE such as parents or custodians of students, or governmental officials from health or education departments. The physical environment column refers to the IHE's physical infrastructure and supporting mechanisms needed to effectively manage a flu pandemic (e.g. ICT facilities for distance learning and the availability of the IHE's healthcare team). The socio-cultural environment column refers to finance, legal, policy, social and cultural practices in the IHE that affect each phase of disaster response, as each phase represents a unique set of challenges. The socio-cultural environment column refers to the macro-level requirements needed for the IHE to provide an efficient response to the pandemic (e.g. improving the socio-cultural awareness of restricted movement or lockdown, non-pharmaceutical interventions such as hand washing and social distancing).

We next drew on five existing public health-related Haddon matrices that possess an education component in their matrix construction, i.e. those set in nursing schools (Centers for Disease Control, 2002; Tiwari et al., 2006), medical 
Mohd Shahir Shamsir et al.

schools (Cole et al., 2020; Grosshuesch, 2010) and school transportation services (Edmonston and Sheehan, 2001). We then identified cell items that were not associated with preparedness opportunities for IHEs and removed them. Next, the recommendations extracted from the 42 reviewed studies were organized and summarized according to axis and added to the matrix in Table 3. The third and final step was to remove items not associated with IHE preparedness for flu outbreak from the original matrix and substitute them with similar items that can be adopted by IHEs. Examples of similar items are those related to risks or disasters affecting a campus such as floods (Tkachuck et al., 2018; Zhong et al., 2013), earthquake (Magni et al., 2017), hurricanes (Ladd et al., 2007) and accidents such as radiation leaks (Osburn, 2008). In the final matrix, each cell represents specific task-oriented items that can be designated to the suitable IHE personnel to solve a particular challenge, a method similar to that used by Runyan (2003).

\section{Application of the Haddon matrix for IHE preparedness and planning}

Using the pre-, during and post-event phases design of the IHE Haddon matrix as a guide, the following section draws on the experiences of Malaysian IHEs during the COVID-19 pandemic. The purpose is to illustrate how the matrix content can be used to identify gaps in preparedness and response to pandemics for IHEs. We present the three phases below in a narrative format in order to highlight how the scenario unfolded and to allow for discussion with relevant literature and policies. Where appropriate, we also provide recommendations from Malaysia's experience on how the elements of the Haddon matrix can be applied in other higher education settings.

\section{Pre-event responses}

Recent history has seen repeated outbreaks of infectious diseases, from the H1N1 swine flu pandemic to the milder H7N9 bird flu. Fortunately, Malaysia has been largely spared from viral outbreaks, with the exception of the 1998 Nipah virus (Chua, 2003) and a hand, foot and mouth disease (HFMD) outbreak in 2018 (BERNAMA/NSTP, 2018). Unfortunately, the low frequency of outbreaks in Malaysia reduced the country's perceived threat level, limiting preparedness to public health institutions only. As a member of WHO, however, Malaysia has begun to increase public health preparedness (World Health Organization, 2004) by embracing the vision of the Asia Pacific Strategy for Emerging Diseases (APSED) - a strategic framework for countries to build the required capacity under the International Health Regulations (Li and Kasai, 2011). The Malaysian government further drafted the country's own strategic document, the Malaysian Strategy for Emerging Diseases (MySED) I Workplan (2012-2015) and MySED II Workplan (2017-2021). However, the need to extend these measures to the creation of infectious disease preparedness plans beyond those for public health institutions 
Mohd Shahir Shamsir et al.

Development of a Haddon Matrix Framework

452

has only occurred in the context of fiscal plans (e.g. hospitality industry [(AlBattat and MatSom, 2014]) or in the form of limited measures such as educational instructions kits for undergraduates (as in MySED II). No evident strategic policy documents have been prepared by the Ministry of Education (MOE) or Ministry of Higher Education (MOHE) for responding to infectious disease outbreaks. As a response, Universiti Sains Malaysia (USM) was the first IHE to produce a guideline and action plan for COVID-19 (Hoe, 2020), followed by Universiti Malaysia Kelantan (UMK) (Taskforce, 2020).

In the context of Malaysian IHEs in the pre-event stage, several factors related to the Haddon matrix were critical in defining the readiness level to react to the pandemic. First is medical and health services. At the onset of the outbreak, university medical support facilities initially did not test, identify or process infected individuals but were only tasked to assist on testing samples taken by Ministry of Health $(\mathrm{MOH})$ personnel. The Malaysian government mandated that this was to be performed by the District Health Offices and local hospitals. Subsequently, only ten diagnostic laboratories from Malaysian IHEs had been approved to join the national testing network (Rafidi, 2020). Health centres of universities without medical schools would complement these efforts by providing other health support services. Future preparations should include upgrading and maintaining the necessary standards of these diagnostic laboratories in IHEs.

The second factor is IHE employee readiness in adapting to working remotely. At the time of the outbreak, Malaysian academic work culture was not familiar with remote working as attendance policies - government universities in particular required all staff to record their daily attendance. Hence, at the time of the COVID19 outbreak, there were no policies or guidelines in most Malaysian IHEs for working remotely. This caused much confusion among staff. Furthermore, past preevent preparedness administration emergency training at Malaysian IHEs and their facilities, such as libraries, was limited to scenarios such as fires, electrical outages and floods (Khalid and Dol, 2015) and did not include the unprecedented scale of the COVID-19 scenario pandemic and the paralysing restricted movement nationwide. The COVID-19 pandemic accelerated the IHE's adoption of distance working and learning practices, that were, at the time of the outbreak, still in development or yet to be implemented on a large scale. IHEs should invest in developing the necessary infrastructure as online learning will constitute a significant portion of teaching and learning in the new COVID-19 and postCOVID-19 environment (Chung et al., 2020).

\section{Event responses}

The speed of the COVID-19 pandemic, which reached 200 countries in less than 3 months, resulted in a faster infection rate (Liu et al., 2020) and higher lethality than the previous SARS and MERS outbreaks combined (Mahase, 2020). The unique characteristics of COVID-19 caught many governments by surprise, delaying early 
Mohd Shahir Shamsir et al.

responses. In Malaysia, the government instituted a Movement Control Order that initially provided little guidance for IHEs and their respective student bodies. This resulted in thousands of students leaving their university campuses to return to their hometowns. Although a clarification was issued two days later by the Ministry of Higher Education (MOHE), almost all campuses were vacated within 48 hours. Some universities were instructed to close earlier due to the campuses being infected by the Sri Petaling cluster (Lim, 2020; Nordin, 2020). This cluster was the main cause of the second wave of COVID-19 outbreak, which was fuelled by a massive Jemaah Tabligh religious gathering outside Kuala Lumpur (Babulal and Othman, 2020). One university closed its campus prior to the issuance of the national MCO because it was the first campus (Lim, 2020) to report COVID-19 infections, and it reported the highest number of infected cases in Malaysia. This decision proved to be critical in mitigating the spread of the virus as the quarantined students were securely isolated, thus reducing their risk of infecting others by leaving campus and returning home. Other universities issued recommendations for students to stay on campus during the initial period (Harun, 2020) with the rest issuing similar instructions after receiving clarification from the Malaysia Ministry of Higher Education (MOHE) and the National Security Council (MKN). The decision also proved to be controversial, as some universities allowed their students to return home (Anis, 2020), rather than quarantining them on campus for an unknown length of time (Abdul Rahman, 2020). The MCO's restricted movement strategy was implemented as a compromise between the extremes of a curfew or total lockdown and a complete freedom of movement strategy as initially adopted by Italy and the UK during the early phase of the outbreak (Giordano et al., 2020).

To manage the pandemic, developments were monitored by IHE disaster management teams, usually consisting of senior university management, health services and campus security. These disaster management teams had three main responsibilities: (1) to gather and analyse data on the COVID-19 situation; (2) to prepare a course of action to combat the virus in regard to human capital and university operations; and (3) to relay information of university decisions and actions to IHE staff and students. Malaysian IHEs quickly created various dedicated disaster management teams to manage the effect of the pandemic to their institutions; Universiti Putra Malaysia (UPM) (Rahman, 2020) and Universiti Malaysia Sabah (UMS) (Mukhsam et al., 2020).

IHEs possess a large reservoir of talent, expertise and manpower, which includes staff and students. The size of many university communities can act as both a threat and a resource (Van et al., 2010). In previous pandemics, youth were considered high risk of infection due to their mobility, therefore making outbreak management essential in reducing risk from IHEs to the public. However, during COVID-19 the transmission dynamics differ from previous pandemics. Susceptible individuals and mortality risk are higher among older populations; hence, it was deemed best to isolate students on campus. This proved to be difficult without additional financial 
allocations, however, as food needed to be delivered to students during the MCO. Furthermore, in university housing, resident advisors, custodial personnel and food service staff required adequate protection when carrying out services. Most Malaysian IHEs coordinated students remaining on campus into housing arrangements with proper physical distancing to manage their welfare (NewstreamAsia, 2020). Malaysian IHE students that were stranded abroad were also repatriated in coordination with the Education Malaysia office in the respective countries (NST, 2020a, b). Foreign students in Malaysian IHEs were given moral and material support on campus (Abdullah, 2020). The experience, expertise and resources provided by alumni were also tapped by opening support channels to the university. IHE could mobilize student volunteers to help with the distribution of food on campus. In the future, steps should be taken to repatriate local students currently residing abroad to return home as soon as possible.

The re-appropriation of research resources in Malaysian IHEs was used early on to mitigate the effects of the COVID-19 pandemic (Shah et al., 2020). Repurposing research capacity and technology allowed several IHEs to contribute to pandemic management in the early stages. These efforts included the use of robots for delivery and disinfecting (AFP, 2020; BERNAMA, 2020; Rahman, 2020), 3D printing (Choong, 2020), sewing of personal protection equipment (PPE) (New Straits Times, 2020a, b) and laboratory testing (Rafidi, 2020). After the initial pandemic period, IHEs pivoted their research capabilities towards more substantial areas such as genome sequencing and vaccine development. Social science research centred around public perception, mental health and business risks associated with the pandemic (Sundarasen et al., 2020).

As social distancing during the MCO was mandated by law in Malaysia, IHEs encouraged behavioural change such as increased hand washing by creating student awareness and promotional materials. Effective awareness campaigns through social media (Phillipson et al., 2013; Wilson and Huttlinger, 2010) and visual signage (Updegraff et al., 2011) have been shown to successfully reduce infections in student populations. During the early stages of the crisis, many IHEs quickly produced social media-based materials to this effect. Efforts included the provision of hand-washing facilities and social media posters encouraging compliance, and openly distributing bottles of sanitizers to staff and students on campus. Regular information feeds were also used to increase awareness among the students regarding the various crisis management measures being implemented.

The implementation of the MCO resulted in a national lockdown with the exception of ten essential services: food, water, energy, communications and internet, security and defence, solid waste and public cleansing management and sewerage, healthcare and medical - including dietary supplements, banking and finance, e-commerce and logistics. This severe movement restriction forced Malaysia IHE staff members to manage unpredictable and extended disruptions to their usual work practices. It is expected that work productivity will decline due to 
Mohd Shahir Shamsir et al.

the shift to working from home. Understanding academic staff members' responses to this situation might also aid future crisis planning.

Prior to the COVID-19 pandemic, Malaysian IHE involvement in disaster planning included emergencies such as fires, floods or man-made incidents on their campuses. These experiences can be sourced to provide a framework for pandemic planning as well. Using such disaster planning units as a model for pandemic response, the committee should be chaired by top IHE management and include participation from all department stakeholders. Working groups should be established within the committee to prepare detailed plans for student affairs, medical, academic and administrative operations. The committee should liaise with local and state health agencies via the Director of the University Medical School or Health Centre. In the future, IHEs should consider using training such as the 'tabletop exercise' to simulate the emergence of COVID-19 and execute emergency management procedures (Wendelboe et al., 2020). Tabletop exercises are low-cost, discussion-based sessions where participants meet in an informal, classroom setting to react to a simulated scenario. The goal is to enable a response team to react to events as they unfold. During the exercise, participants discuss their respective roles and appropriate responses during an emergency. Tabletop exercises are used to validate organizational emergency planning and capabilities, clarify roles and responsibilities and to identify further mitigation and preparedness requirements (Dausey et al., 2007). When IHEs use the tabletop exercise for planning, government responses such as control and movement restrictions can be considered and planned for.

\section{Post-event responses}

The post-event stage in the Haddon matrix deals with the recovery period. This stage includes measures taken to address the possibility of recurring infections and managing the psychological impact of the changes that occurred as a result of the pandemic. This period requires active illness surveillance, making screening and quarantine facilities for students returning to campus housing a requirement. Campus dormitory and administration buildings must also be decontaminated before re-opening. The functionality of IHE health care centres must be fully operational in anticipation of new cases. Financial or material aid should be pursued from both public and private sources to pay for these expenses. Given the high number of infections at certain Malaysian IHEs, campus buildings had to be decontaminated, and ongoing support for staff and students has been extensive. Fatalities due to infection at certain universities required additional support services including counselling for staff and students (Sundarasen et al., 2020). To recover the momentum of teaching and learning, methods of delivery due to physical distancing requirements need to be re-considered. This was particularly true for Malaysian IHEs involved in the teaching of subjects requiring field practice such as clinical courses (Ahmad et al., 2017) and social work (Azman et al., 2020). 
Mohd Shahir Shamsir et al.

Development of a Haddon Matrix Framework

456

\section{Conclusion}

In the wake of global pandemics and other major health events, national health officials often work to improve their public health capacities by building on the lessons learned to formulate evidence-based strategies for preparedness (Montgomery et al., 2019). In anticipation of future outbreaks, pandemic planning to date has been formulated mostly by business entities and nation states. With the severity of the COVID-19 pandemic, however, planning must now be extended to nontraditional entities such as the education industry (Mounier-Jack and Coker, 2006). The early COVID-19 lessons learned from Malaysian IHEs indicate that IHEs have the capability to adapt their management practices to respond to pandemic events; however, systematic planning and preparation are essential.

In summary, the findings and subsequent recommendations from the scoping review of past IHE responses to pandemics indicate that procedures and policies can be formulated to respond effectively to the pre-event, event and post-event phases, and should include broad management themes with a primary focus on student well-being. The sheer magnitude of the COVID-19 crisis is unprecedented, making past IHE responses as a reference for Haddon matrix inadequate. The IHE Haddon matrix represents an initial attempt to develop a planning and readiness tool specifically for IHEs towards the development of policies relating to institutional responses to global pandemics. Hence, the matrix can be further developed as the COVID-19 pandemic progresses.

\section{Acknowledgements}

This study was supported by the Malaysian Ministry of Higher Education's Research University Network Grant (UPM/800-4/11/MRUN/2018/5539210).

\section{Compliance with Ethical Standards}

Conflict of interest On behalf of all authors, the corresponding author states that there is no conflict of interest.

\section{References}

Abdul Rahman, D. A. (2020) 'COVID-19: UniMAP sedia 30 bas hantar pelajar pulang', Berita Harian, 18 March.

Abdullah, M. F. (2020) 'Staying on campus during MCO a strain on students', New Straits Times, 14 April.

Adnan, M. and Anwar, K. (2020) 'Online learning amid the COVID-19 pandemic: students' perspectives', Online Submission 2(1): 45-51.

AFP. (2020) 'Medibot' to do rounds on Malaysia's Covid-19 wards', New Straits Times, 13 April. 
Mohd Shahir Shamsir et al.

Ahmad, I., Altaf, S. and Ahmad, H. M. (2017) 'Assessment of knowledge, practice and barrier in use of facemask among university students', Pakistan Journal of Medical \& Health Sciences 11(4): $1657-58$.

Akan, H. (2010) 'Knowledge and attitudes of university students toward pandemic influenza: a crosssectional study from Turkey', BMC Public Health 10(1): 413.

Al-Muhafda, Z., Qaher, M., Faisal, E., Abushahla, H., Kurdi, R. and Al-Jayyousi, G. (2016) 'Knowledge of MERS-Corona Virus among female students at Qatar University', In Qatar Foundation Annual Research Conference Proceedings Volume 2016 Issue 1 (Vol. 2016, No. 1, p. HBSP3348). Hamad bin Khalifa University Press (HBKU Press).

Al-Naggar, R. A., Al Jashamy, K. and Bobryshev, Y. V. (2015) 'Knowledge of Malaysian university students towards Swine-Origin Influenza A (H1N1) Virus: a qualitative study', International Archives of Medicine 8(12): 1-7.

AlBattat, A. R. and MatSom, A. P. (2014) 'Emergency planning and disaster recovery in malaysian hospitality industry', Procedia - Social and Behavioral Sciences 144: 45-53.

Anis, M. N. (2020) 'Covid-19: move to send UPSI students home temporarily halted', The Star, 14 May.

Anparasan, A. and Lejeune, M. (2017) 'Analyzing the response to epidemics: concept of evidence-based Haddon Matrix', Journal of Humanitarian Logistics and Supply Chain Management 7(3): 266-283.

Araz, O. M., Lant, T., Fowler, J. W. and Jehn, M. (2011) 'A simulation model for policy decision analysis: a case of pandemic influenza on a university campus', Journal of Simulation 5(2): 89-100.

Arinaminpathy, N., Raphaely, N., Saldana, L., Hodgekiss, C., Dandridge, J., Knox, K. and McCarthy, N. D. (2012) 'Transmission and control in an institutional pandemic Influenza A(H1N1) 2009 outbreak', Epidemiology and Infection, 140(6): 1102-1110.

Arnold, J. L. (2005) 'The 2005 London bombings and the Haddon Matrix', Prehospital and Disaster Medicine 20(5): 278-81.

Azman, A., Jamir Singh, P. S., Parker, J. and Crabtree, S. A. (2020) 'Addressing competency requirements of social work students during the COVID-19 pandemic in Malaysia', Social Work Education advance online publication August 28. https://doi.org/10.1080/02615479.2020.1815692.

Babulal, V. and Othman, N. Z. (2020) 'Sri Petaling Tabligh gathering remains Msia's largest Covid-19 cluster', New Straits Times, 11 April.

Barnett, D. J., Balicer, R. D., Lucey, D. R. Everly Jr, G. S., Omer, S. B., Steinhoff, M. C. and Grotto, I. (2005b) 'A systematic analytic approach to pandemic influenza preparedness planning', PLoS Med 2(12): e359.

Barnett, D. J., Balicer, R. D., Blodgett, D., Fews, A. L., Parker, C. L. and Links, J. M. (2005a) 'The application of the Haddon Matrix to public health readiness and response planning', Environmental Health Perspectives 113(5): 561-566.

Beaton, R., Stergachis, A., Thompson, J., Osaki, C., Johnson, C., Charvat, S. J. and Marsden-Haug, N. (2007) 'Pandemic policy and planning considerations for universities: findings from a tabletop exercise', Biosecurity and Bioterrorism: Biodefense Strategy, Practice, and Science 5(4): 327-334.

Berg, J. E., Grimeland, J. and Jacobsen, I. W. (2014) 'Risk perception of seasonal and swine influenza among university college students: does study direction influence attitudes', Journal of Health Science 2: 89-93.

BERNAMA. (2020) 'UTM, partners create 'makcik kiah 19' delivery robot', 8 April.

BERNAMA/NSTP. (2018) 'HFMD cases near 38,000 nationwide since January', New Straits Times, 28 July.

Centers for Disease Control. (2002) 'Bioterrorism and emergency readiness: competencies for all public health workers', https://www.hsdl.org/?abstract\&did=770983.

Cheng, C. and Cheung, M. W. L. (2005) 'Psychological responses to outbreak of severe acute respiratory syndrome: a prospective, multiple time-point study', Journal of Personality 73(1): 261-85.

Cheng, Q. and Xu, Y. (2008) 'The application of the Haddon Matrix model in the health education of rural emergent events in China', Modern Preventive Medicine 20. 
Mohd Shahir Shamsir et al.

Development of a Haddon Matrix Framework

458

Choe, Y. J. 2017. “An outbreak of Measles in a University in Korea, 2014.” Journal of Korean Medical Science 32(11): 1876-1878.

Choi, J. S. and Yang, N. Y. (2010) 'Perceived knowledge, attitude, and compliance with preventive behavior on influenza A (H1N1) by university students', Korean Journal of Adult Nursing 22(3): 250-259.

Choong, J. (2020) 'Health Ministry, UTM collaborate on three projects for Covid-19 Care', Malay Mail, 13 April.

Chua, K. B. (2003) 'Nipah Virus outbreak in Malaysia', Journal of Clinical Virology 26(3): 265-275.

Chung, E., Subramaniam, G. and Christ Dass, L. (2020) 'Online learning readiness among university students in Malaysia amidst Covid-19', Asian Journal of University Education 16(2): 45-58.

Cole, G., Rosenblum, A. J., Boston, M. and Barnett, D. J. (2020) 'Applying the Haddon Matrix to hospital earthquake preparedness and response', Disaster Medicine and Public Health Preparedness advance online publication April 7 https://doi.org/10.1017/dmp.2020.30.

Coveleski, J. (2014) 'A study of students' perceptions of natural disaster plans and emergency preparedness at a higher education institution', Ph.D. dissertation, Department of Educational Leadership and Policy Studies, Florida State University.

Crawford, J., Butler-Henderson, K., Rudolph, J., Malkawi, B., Glowatz, M., Burton, R., Magni, P. and Lam, S. (2020). 'COVID-19: 20 countries' higher education intra-period digital pedagogy responses', Journal of Applied Learning \& Teaching 3(1): 1-20.

Culliton, B. J. (1990) 'Emerging viruses, emerging threat', Science 247: 279+.

Daudt, H. M. L., Van Mossel, C. and Scott, S. J. (2013) 'Enhancing the Scoping study methodology: a large, inter-professional team's experience with Arksey and O'Malley's framework', BMC Medical Research Methodology 13(1): 48.

Dausey, D. J., Buehler, J. W. and Lurie, N. (2007) 'Designing and conducting tabletop exercises to assess public health preparedness for manmade and naturally occurring biological threats', $B M C$ Public Health 7(1): 92.

Dhawan, S. (2020) 'Online learning: A panacea in the time of COVID-19 crisis', Journal of Educational Technology Systems 49(1): 5-22.

Edmonston, C. J. and Sheehan, M. C. (2001) 'Safe school travel is no accident! Applying the Haddon Matrix to school transport safety', In Proceedings of the 2001: Road Safety Research, Policing and Education Conference Volume 2 (pp. 110-117). Conference Management Office Monash University.

Ekmekci, O. and Bergstrand, J. (2010) 'Agility in higher education: planning for business continuity in the face of an H1N1 pandemic', SAM Advanced Management Journal 75(4): 20.

Engström, K. G., Angrén, J., Björnstig, U. and Saveman, B. I. (2018) 'Mass casualty incidents in the underground mining industry: applying the Haddon Matrix on an integrative literature review', Disaster Medicine and Public Health Preparedness 12(1): 138-146.

Etokidem, A. J., Ago, B. U., Mgbekem, M., Etim, A., Usoroh, E. and Isika, A. (2018) 'Ebola virus disease: assessment of knowledge, attitude and practice of nursing students of a Nigerian University', African health sciences, 18(1): 55-65.

Gates, B. (2015) 'The next epidemic - lessons from Ebola', New England Journal of Medicine 372(15): 1381-1384.

Gates, B. (2020) 'Responding to Covid-19 - a once-in-a-century pandemic?', The New England Journal of Medicine 382(18): 1677-1679.

Ghebreyesus, T.A. (2020) 'WHO Director-General's opening remarks at the media briefing on COVID19', https://www.who.int/dg/speeches/detail/who-director-general-s-opening-remarks-at-the-mediabriefing-on-covid-19 3-march-2020, accessed 24 March 2020.

Giordano, G., Blanchini, F., Bruno, R., Colaneri, P., Di Filippo, A., Di Matteo, A. and Colaneri, M. (2020) 'Modelling the COVID-19 epidemic and implementation of population-wide interventions in Italy', Nature Medicine, 1-6. 
Mohd Shahir Shamsir et al.

Greenland, K., Whelan, J., Fanoy, E., Borgert, M., Hulshof, K., Yap, K. B. and Hahné, S. (2012) 'Mumps outbreak among vaccinated university students associated with a large party, the Netherlands, 2010', Vaccine 30(31): 4676-4680.

Grosshuesch, A. R. (2010) 'Staffing a major academic medical center during a long term disaster', Ph.D. Dissertation, Department of Psychology, Appalachian State University.

Gu, J., Zhong, Y., Hao, Y., Zhou, D., Tsui, H., Hao, C. and Lau, J. T. F. (2015) 'Preventive behaviors and mental distress in response to H1N1 among university students in Guangzhou, China', Asia Pacific Journal of Public Health 27(2): NP1867-NP1879.

Gusenbauer, M. (2019) 'Google Scholar to overshadow them all? comparing the sizes of 12 academic search engines and bibliographic databases', Scientometrics 118(1): 177-214.

Haddon, W. (1968) 'The changing approach to the epidemiology, prevention, and amelioration of trauma: the transition to approaches etiologically rather than descriptively based', American Journal of Public Health and the Nations Health 58(8), 1431-1438.

Harun, H. N. (2020) 'USM students urged to stay put', New Straits Times, 12 April.

Hoe, T.E. (2020) 'USM first university in Malaysia to devise guideline and action plan on COVID-19 Pandemic', USM News, 3 April.

Hoehl, S., Rabenau, H., Berger, A., Kortenbusch, M., Cinatl, J., Bojkova, D. and Neumann, P. (2020) 'Evidence of SARS-CoV-2 infection in returning travelers from Wuhan, China', New England Journal of Medicine 382(13): 1278-1280.

Holloway, R., Rasmussen, S. A., Zaza, S., Cox, N. J., Jernigan, D. B. and Influenza Pandemic Framework Workgroup. (2014) 'Updated preparedness and response framework for influenza pandemics', Morbidity and Mortality Weekly Report: Recommendations and Reports 63(6): 1-18.

Hutton, A., Savage, C., Ranse, J., Finnell, D. and Kub, J. (2015) 'The use of Haddon's matrix to plan for injury and illness prevention at outdoor music festivals', Prehospital and Disaster Medicine 30(2): 175.

Jacob, O. N., Abigeal, I. and Lydia, A. E. (2020) 'Impact of COVID-19 on the higher institutions development in Nigeria', Electronic Research Journal of Social Sciences and Humanities 2(2): 126-135.

Kakkar, M., Hazarika, S., Zodpey, S. and Reddy, K. S. (2010) 'Influenza pandemic preparedness and response: A review of legal frameworks in India', Indian Journal of Public Health 54(1), 11.

Kamal, N. N. and Seedhom, A. E. (2011) 'Knowledge, attitude and practice of El-Minia university students towards pandemic H1N1, Egypt, 2009', Journal of Public Health 19(6): 505-510.

Khalid, S. J. M. and Dol, N. (2015) 'Disaster preparedness for academic libraries in Malaysia: an exploratory study', International Journal of Humanities and Social Sciences 9(10): 2946-2952.

Koskan, A., Foster, C., Karlis, J. and Tanner, A. (2012) 'Characteristics and influences of H1N1 communication on college students', Disaster Prevention and Management: An International Journal 21(4): 418-432.

Ladd, A. E., Gill, D. A. and Marszalek, J. (2007) 'Riders from the storm: Disaster narratives of relocated New Orleans college students in the aftermath of Hurricane Katrina', Journal of Public Management and Social Policy 13(2): 51-80.

Li, A. and Kasai, T. (2011) 'The Asia Pacific strategy for emerging diseases-a strategy for regional health security', Western Pacific Surveillance and Response Journal: WPSAR 2(1): 6.

Lim, I. (2020). 'Covid-19: Johor's UTHM suspends lessons, gatherings after one university staff tests positive', Malay Mail, 15 March.

Liu, Y., Gayle, A. A., Wilder-Smith, A. and Rocklöv, J. (2020) 'The reproductive number of COVID-19 is higher compared to SARS coronavirus', Journal of Travel Medicine, 1-4.

López-Cózar, E. D., Orduña-Malea, E. and Martín-Martín, A. (2019) 'Google Scholar as a data source for research assessment." In Springer handbook of science and technology indicators (pp. 95-127). Springer, Cham. 
Magni, M., Fraboni, R. and Marincioni, F. (2017) 'Emergency preparedness and management at the University of L'aquila (Central Italy) and the role of students' associations in the April 6th 2009 earthquake', PLoS Currents, 9.

Mahase, E. (2020) 'Coronavirus: Covid-19 has killed more people than SARS and MERS combined, despite lower case fatality rate', 368: m641.

Maier, K., Berkman, J. and Chatkoff, D. (2012) 'Novel virus, atypical risk group: Understanding young adults in college as an under-protected population during H1N1 2009', PLoS Currents, 4.

Marinoni, G., van't Land, H. and Jensen, T. (2020) 'The impact of Covid-19 on higher education around the world', IAU Global Survey Report, International Association of Universities.

Martin-Martin, A., Orduña-Malea, E., Harzing, A. W. and López-Cózar, E. D. (2017) 'Can we use Google Scholar to identify highly-cited documents?', Journal of Informetrics 11(1): 152-163.

Meyers, J., Logaraj, M., Ramraj, B., Narasimhan, P. and MacIntyre, C. R. (2018) 'Epidemic varicella zoster virus among university students, India', Emerging Infectious Diseases 24(2): 366.

Mitchell, T., Dee, D. L., Phares, C. R., Lipman, H. B., Gould, L. H., Kutty, P. and Siebold, J. (2011) 'Non-pharmaceutical interventions during an outbreak of 2009 pandemic influenza A (H1N1) virus infection at a large public university, April-May 2009', Clinical Infectious Diseases, 52(suppl_1): S138-S145.

Mitchell, T., Massoudi, M., Swerdlow, D. L., Dee, D. L., Gould, L. H., Kutty, P. K. and Fishbein, D. B. (2014) 'Swine flu in college: early campus response to outbreak control measures', American Journal of Health Behavior 38(3): 448-464.

Montgomery, J. M., Woolverton, A., Hedges, S., Pitts, D., Alexander, J., Ijaz, K. and Henao, O. (2019) 'Ten years of global disease detection and counting: program accomplishments and lessons learned in building global health security', BMC Public Health 19(Suppl 3): 510.

Morse, S. S. and Schluederberg, A. (1990) 'Emerging viruses: the evolution of viruses and viral diseases', The Journal of infectious Diseases 162(1): 1-7.

Mounier-Jack, S. and Coker, R. J. (2006) 'How prepared is Europe for pandemic influenza? Analysis of national plans', The Lancet 367(9520): 1405-1411.

Mukhsam, M. H., Jeffree, M. S., Pang, N. T. P., Rahim, S. S. S. A., Omar, A., Abdullah, M. S. and Saupin, S. (2020) 'A university-wide preparedness effort in the alert phase of COVID-19 incorporating community mental health and task-shifting strategies: experience from a Bornean institute of higher learning', The American Journal of Tropical Medicine and Hygiene 103(3): 1201-1203.

New Straits Times. (2020) 'UMK makes PPE and shield visors for Covid-19 frontliners', New Straits Times, 30 March.

New Straits Times. (2020) '40 Malaysian students in Beijing return home', New Straits Time, 1 February.

NewstreamAsia. (2020) University students on campus are well taken care of during transit. 1 April, http://www.newstream.asia/community/university-students-on-campus-are-well-taken-care-ofduring-transit/, accessed 16 September.

Nordin, R. (2020) 'UTHM Postpones all activities, gatherings after staff member tested positive for Covid-19', The Star Online, 15 March, https://www.thestar.com.my/news/nation/2020/03/15/uthmpostpones-all-activities-gatherings-after-staff-member-tested-positive-for-covid-19, accessed 30 March.

Osburn, T. W. (2008). Hazard mitigation and disaster preparedness planning at american coastal university: seeking the disaster-resistant university', PhD Dissertation, University of North Texas.

Pappas, G., Panagopoulou, P. and Akritidis, N. (2009) 'Reclassifying bioterrorism risk: are we preparing for the proper pathogens?', Journal of Infection and Public Health 2(2): 55-61.

Park, J. H., Cheong, H. K., Son, D. Y., Kim, S. U. and Ha, C. M. (2010) 'Perceptions and behaviors related to hand hygiene for the prevention of H1N1 influenza transmission among Korean university students during the peak pandemic period', BMC Infectious Diseases 10(1): 222. 
Mohd Shahir Shamsir et al.

Park, S. W., Jang, H. W., Choe, Y. H., Lee, K. S., Ahn, Y. C., Chung, M. J. and Han, T. (2016) 'Avoiding student infection during a Middle East respiratory syndrome (MERS) outbreak: a single medical school experience', Korean Journal of Medical Education 28(2): 209.

Phillipson, L., Jones, S. C., Larsen-Truong, K., Robinson, L. and Barrie, L. (2013) 'Using social marketing to promote cold and flu prevention behaviors on an Australian university campus', Faculty of Social Sciences - Papers, 1251.

Phua, K. L. (2015) 'Meeting the challenge of Ebola virus disease in a holistic manner by taking into account socioeconomic and cultural factors: the experience of West Africa', Infectious Diseases: Research and Treatment, 8: IDRT-S31568.

Rafidi, R. (2020). 'Malaysian varsities join Covid-19 testing battle', New Straits Times, 8 April.

Rahman, A. A. (2020) 'UPM Emergency Response Team (ERT-UPM COVID-19) I PUTRA International Centre (i-PUTRA)', UPM NEWS, 2 April.

Rahman, F. (2020) 'The Malaysian response to COVID-19: building preparedness for 'surge capacity', testing efficiency and containment', European Pharmaceutical Review, https://www. europeanpharmaceuticalreview.com/article/125084/the-malaysian-response-to-covid-19-buildingpreparedness-for-surge-capacity-testing-efficiency-and-containment/, accessed 10 September.

Ramsey, M. A. and Marczinski, C. A. (2011) 'College students' perceptions of H1N1 flu risk and attitudes toward vaccination', Vaccine 29(44): 7599-7601.

Rapanta, C., Botturi, L., Goodyear, P., Guàrdia, L., and Koole, M. (2020) 'Online university teaching during and after the Covid-19 crisis: Refocusing teacher presence and learning activity', Postdigital Science and Education, 1-23.

Rautiainen, R., Lehtola, M. M., Day, L. M., Schonstein, E., Suutarinen, J., Salminen, S. and Verbeek, J. H. (2008) 'Interventions for preventing injuries in the agricultural industry', Cochrane Database of Systematic Reviews, https://www.cochranelibrary.com/cdsr/doi/10.1002/14651858.CD006398.pub2/ full, accessed 5 August.

Reperant, L. A. and Osterhaus, A. D. (2017) 'AIDS, Avian flu, SARS, MERS, Ebola, Zika what next?', Vaccine 35(35): 4470-4474.

Riccardo, F., Suk, J. E., Espinosa, L., Bella, A., Giambi, C., Del Manso, M. and Declich, S. (2018) 'Key dimensions for the prevention and control of communicable diseases in institutional settings: a scoping review to guide the development of a tool to strengthen preparedness at migrant holding centres in the EU/EEA', International Journal of Environmental Research and Public Health 15(6): 1120.

Rogers, B. and Lawhorn, E. (2007) 'Disaster preparedness: occupational and environmental health professionals' response to Hurricanes Katrina and Rita,' AAOHN Journal 55(5): 197-207.

Runyan, C. W. (2003) 'Introduction: back to the future-revisiting Haddon's conceptualization of injury epidemiology and prevention', Epidemiologic Reviews 25(1): 60-64.

Ryu, W. S. (2017) Molecular Virology of Human Pathogenic Viruses, London: Elsevier.

Salman, M., Shehzadi, N., Hussain, K., Saleem, F., Khan, M. T., Asif, N. and AbuBakar, U. (2017) 'Knowledge of Ebola virus disease among a university population: a cross-sectional study', American Journal of Infection Control 45(2): e23-e25.

Schlenker, E. H., Tschetter, R. L. and Straub, H. R. (2013) 'Influence of the H1N1 pandemic on university students' knowledge of influenza', South Dakota Medicine 66(11): 449-457.

Seale, H., McLaws, M. L., Van, D., Crimmins, J. and MacIntyre, C. R. (2011) 'University communication strategies during a pandemic - were the messages received?', Journal of Public Health Management and Practice 17(1): E29-E32.

Seale, H., Mak, J. P., Razee, H. and MacIntyre, C. R. (2012) 'Examining the knowledge, attitudes and practices of domestic and international university students towards seasonal and pandemic influenza', BMC Public Health 12(1): 307. 
Mohd Shahir Shamsir et al.

Development of a Haddon Matrix Framework

462

Shah, A. U. M., Safri, S. N. A., Thevadas, R., Noordin, N. K., Abd Rahman, A., Sekawi, Z. and Sultan, M. T. H. (2020). COVID-19 outbreak in Malaysia: actions taken by the Malaysian government. International Journal of Infectious Diseases 97: 108-116.

Shenoy, V., Mahendra, S. and Vijay, N. (2020) 'COVID 19 lockdown technology adaption, teaching, learning, students engagement and faculty experience', Mukt Shabd Journal 9(4): 698-702.

Soto Mas, F., Olivárez, A., Jacobson, H. E., Hsu, C. E. and Miller, J. (2011). Risk communication and college students: The $2009 \mathrm{H} 1 \mathrm{~N} 1$ pandemic influenza', Preventive Medicine: An International Journal Devoted to Practice and Theory 52(6): 473-474.

Sundarasen, S., Chinna, K., Kamaludin, K., Nurunnabi, M., Baloch, G. M., Khoshaim, H. B. and Sukayt, A. (2020) 'Psychological impact of Covid-19 and lockdown among university students in Malaysia: implications and policy recommendations', International Journal of Environmental Research and Public Health 17(17): 6206.

Suresh, P. S., Thejaswini, V. and Rajan, T. (2011) 'Factors associated with 2009 pandemic influenza A (H1N1) vaccination acceptance among university students from India during the post-pandemic phase', BMC Infectious Diseases 11(1): 205.

Surgeoner, B. V., Chapman, B. J. and Powell, D. A. (2009) 'University students' hand hygiene practice during a gastrointestinal outbreak in residence: what they say they do and what they actually do', Journal of Environmental Health 72(2): 24-29.

Taskforce, UMK. (2020) Pelan Respons Dan Kesiapsiagaan Bagi Covid-19 Dan Penyakit Berjangkit Yang Lain. Kota Bharu. http://www.umk.edu.my/covid19/BOOK_Pelan-RR-COVID-UMK-ver1.pdf, accessed 16 September.

Taylor, L. H., Latham, S. M. and Woolhouse, M. E. (2001) 'Risk factors for human disease emergence', Philosophical Transactions of the Royal Society of London. Series B: Biological Sciences 356(1411): 983-989.

Teng-Teng, B. U. (2015) 'The research on kindergarden security management based on haddon matrix', Journal of Weifang Engineering Vocational College (2): 15.

Tiwari, A., Tarrant, M., Yuen, K. H., Chan, S., Kagan, S., Ching, P. and Wong, S. S. (2006) 'Preparedness for influenza pandemic in Hong Kong nursing units', Journal of Nursing Scholarship 38(4): 308-313.

Tkachuck, M. A., Schulenberg, S. E. and Lair, E. C. (2018) 'Natural disaster preparedness in college students: Implications for institutions of higher learning', Journal of American College Health 66(4): 269-279.

Tork, H. M. and Mersal, F. A. (2018) 'Middle East Respiratory Syndrome-Corona virus: Knowledge and attitude of Qassim University students, KSA', Global Adv Res J Med Med Sci 7(4): 90-7.

Townley, K. F. and McKnight, R. H. (1994) 'Developmentally inappropriate play areas in rural day care: is it safe to play outdoors?', Pediatrics 94(6): 1050.

Uchida, M., Tsukahara, T., Kaneko, M., Washizuka, S. and Kawa, S. (2012) 'How the H1N1 influenza epidemic spread among university students in Japan: experience from Shinshu University', American Journal of Infection Control 40(3): 218-220.

Updegraff, J. A., Emanuel, A. S., Gallagher, K. M. and Steinman, C. T. (2011) 'Framing flu prevention-An experimental field test of signs promoting hand hygiene during the 2009-2010 H1N1 pandemic', Health Psychology, 30(3): 295.

Van, D., McLaws, M. L., Crimmins, J., MacIntyre, C. R. and Seale, H. (2010) 'University life and pandemic influenza: Attitudes and intended behaviour of staff and students towards pandemic (H1N1) 2009', BMC Public Health 10(1): 130.

Varney, S., Hirshon, J. M., Dischinger, P. and Mackenzie, C. (2006) 'Extending injury prevention methodology to chemical terrorism preparedness: the Haddon Matrix and sarin', American Journal of Disaster Medicine 1(1): 18-27.

Virk, R. K., Gunalan, V., Lee, H. K., Inoue, M., Chua, C., Tan, B. H. and Tambyah, P. A. (2017) 'Molecular evidence of transmission of influenza A/H1N1 2009 on a university campus', PloS One 12(1): e0168596. 
Mohd Shahir Shamsir et al.

Wang, C., Cheng, Z., Yue, X.-G. and McAleer, M. (2020) 'Risk management of COVID-19 by universities in China', J. Risk Financial Manag. 13: 36.

Wendelboe, A. M., Amanda Miller, J. D., Drevets, D., Salinas, L., Miller, E. J., Jackson, D. and Public Health Working Group. (2020) 'Tabletop exercise to prepare institutions of higher education for an outbreak of COVID-19', Journal of Emergency Management 18(2): 1-20.

Wilson, S. and Huttlinger, K. (2010) 'Pandemic flu knowledge among dormitory housed university students: a need for informal social support and social networking strategies', Rural and Remote Health 10(4): 1-9.

Wilson, M. G., Lavis, J. N. and Guta A. (2012a) "Community-Based Organizations in the Health Sector: A Scoping Review." Health Research Policy and Systems.

Wilson, M. G., Lavis, J. N. and Guta, A. (2012b) 'Community-based organizations in the health sector: a scoping review', Health Research Policy and Systems 10(1): 36.

Wong, J. G., Cheung, E. P., Cheung, V., Cheung, C., Chan, M. T., Chua, S. E. and Ip, M. S. (2004) 'Psychological responses to the SARS outbreak in healthcare students in Hong Kong', Medical Teacher 26(7): 657-659.

Wong, T. W., Gao, Y. and Tam, W. W. S. (2007) 'Anxiety among university students during the SARS epidemic in Hong Kong', Stress and Health: Journal of the International Society for the Investigation of Stress 23(1): 31-35.

World Health Organization. (2004) 'Informal consultation on influenza pandemic preparedness in countries with limited resources', Kuala Lumpur, Malaysia, 23-25 June, Department of Communicable Disease Surveillance and Response, Geneva.

Xu, J., Zheng, Y., Wang, M., Zhao, J., Zhan, Q., Fu, M. and Cheng, Y. (2011) 'Predictors of symptoms of posttraumatic stress in Chinese university students during the $2009 \mathrm{H} 1 \mathrm{~N} 1$ influenza pandemic', Medical Science Monitor: International Medical Journal of Experimental and Clinical Research 17(7): PH60.

Yan, T. C. and Yu, M. (2019) 'Using the Haddon matrix to explore medical response strategies for terrorist subway bombings', Military Medical Research 6(1): 4.

Yang, S. and Cho, S. I. (2017). 'Middle East respiratory syndrome risk perception among students at a university in South Korea, 2015', American Journal of Infection Control 45(6): e53-e60.

Ye-hua, S. (2006) 'The discussion of the Haddon Matrix to public health emergency readiness and response', Chinese Journal of Disease Control and Prevention, http://en.cnki.com.cn/Article_en/ CJFDTotal-JBKZ200606017.htm, accessed 7 July 2020.

Zhang, Y. Z., Dong, X., Li, X., Ma, C., Xiong, H. P., Yan, G. J. and Zou, Y. (2009) 'Seoul virus and hantavirus disease, Shenyang, People's Republic of China', Emerging Infectious Diseases 15(2): 200.

Zhong, S., Clark, M., Hou, X. Y., Zang, Y. L. and FitzGerald, G. (2013) '2010-2011 Q ueensland floods: Using $\mathrm{H}$ addon's $\mathrm{M}$ atrix to define and categorise public safety strategies', Emergency Medicine Australasia 25(4): 345-352.

Zhong, S., Clark, M., Hou, X. Y., Zang, Y. and FitzGerald, G. (2014) 'Progress and challenges of disaster health management in China: a scoping review', Global Health Action 7(1): 24986.

Publisher's Note Springer Nature remains neutral with regard to jurisdictional claims in published maps and institutional affiliations.

\section{Appendix: Scoping review of selected studies}


Mohd Shahir Shamsir et al.

Development of a Haddon Matrix Framework

464

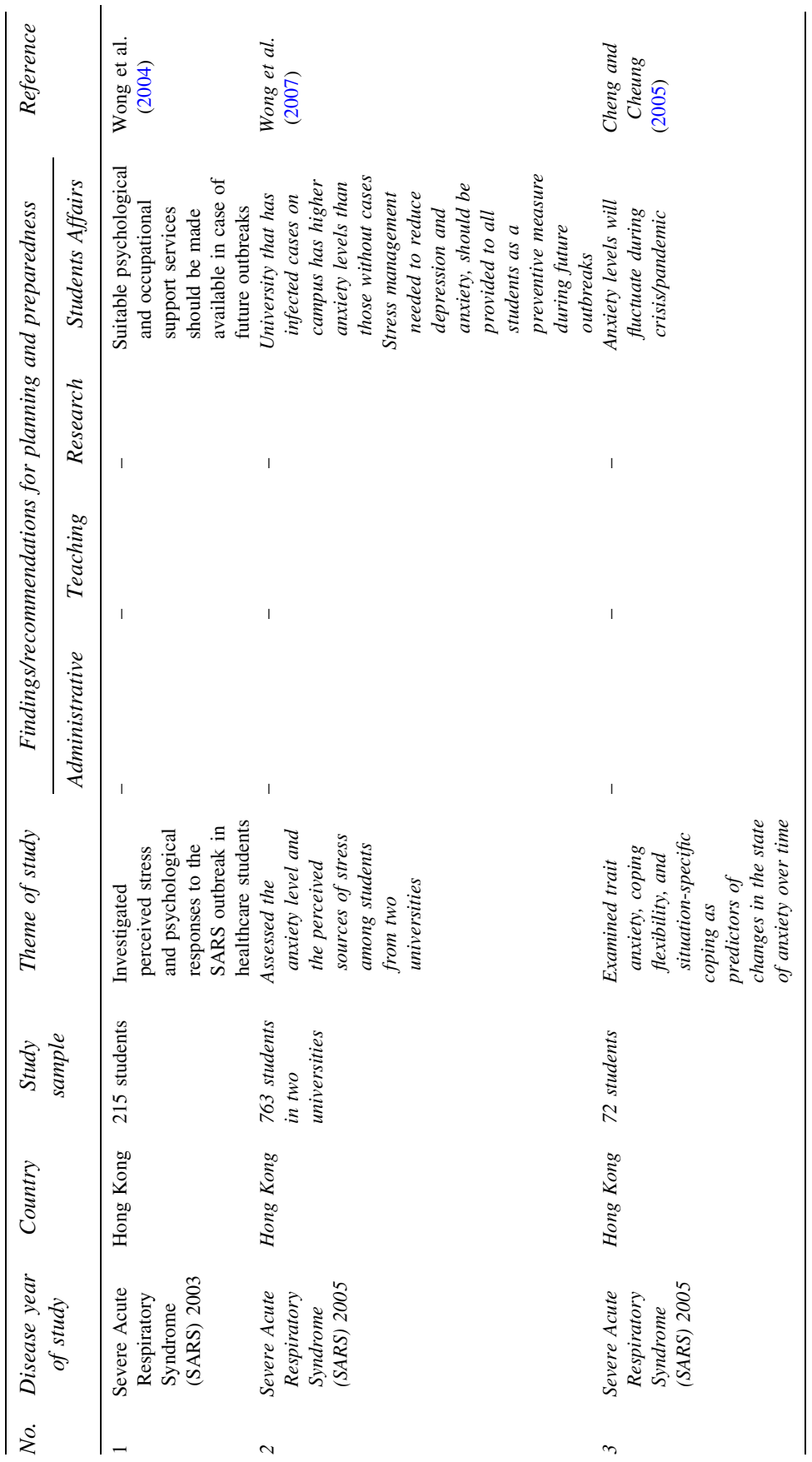

Higher Education Policy 202235 
Mohd Shahir Shamsir et al.

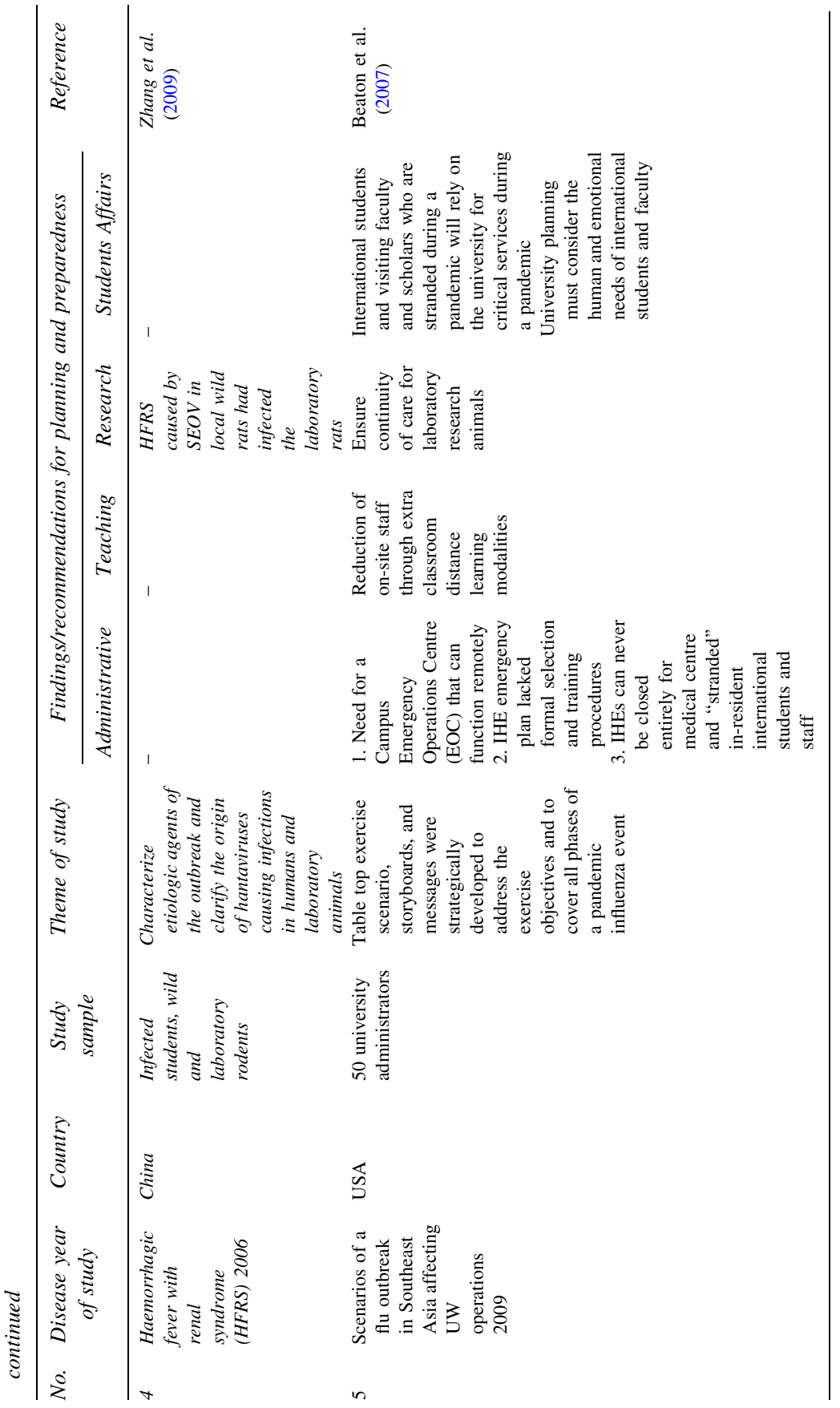


Mohd Shahir Shamsir et al.

Development of a Haddon Matrix Framework

466

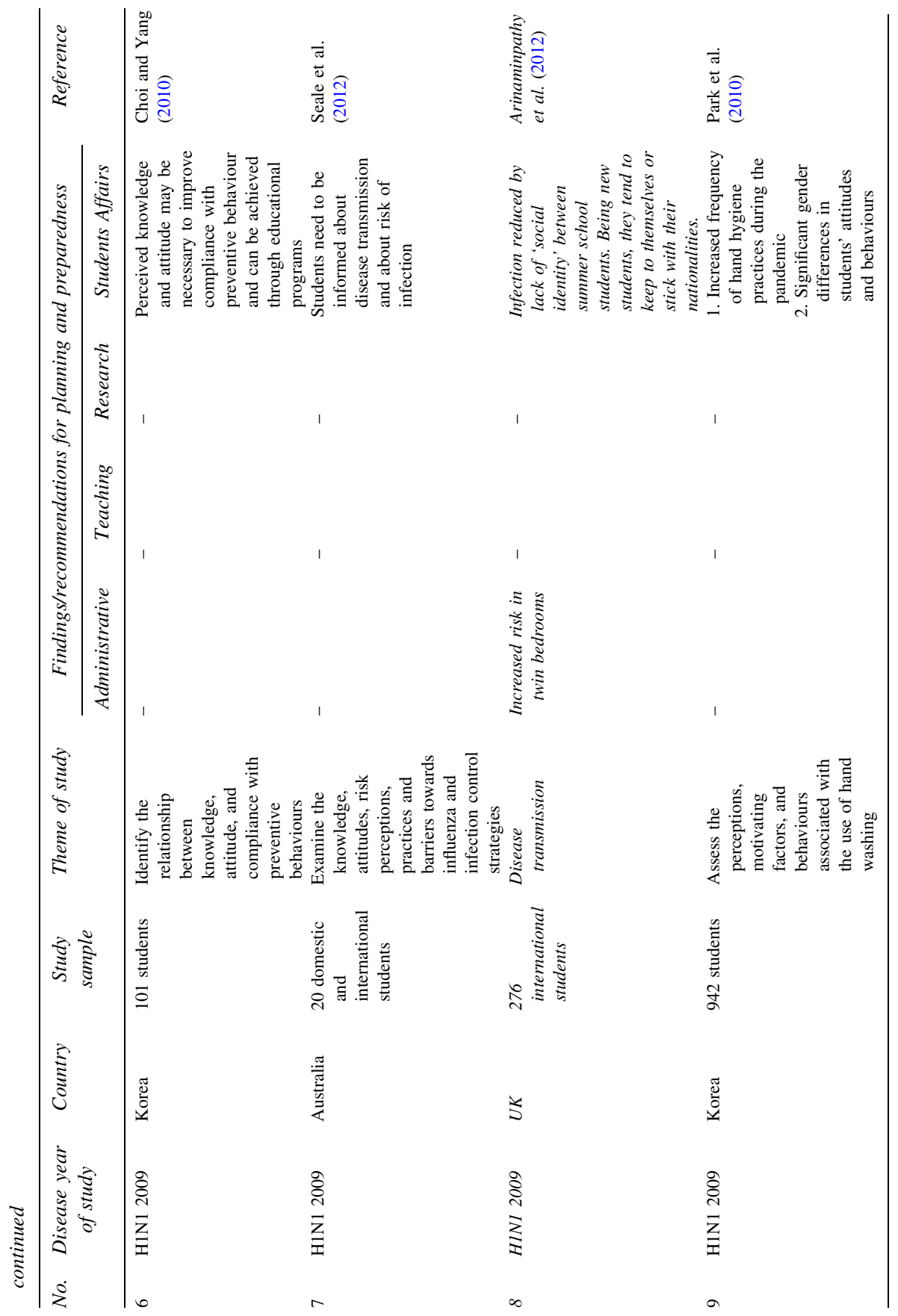

Higher Education Policy 202235 
Mohd Shahir Shamsir et al. Development of a Haddon Matrix Framework

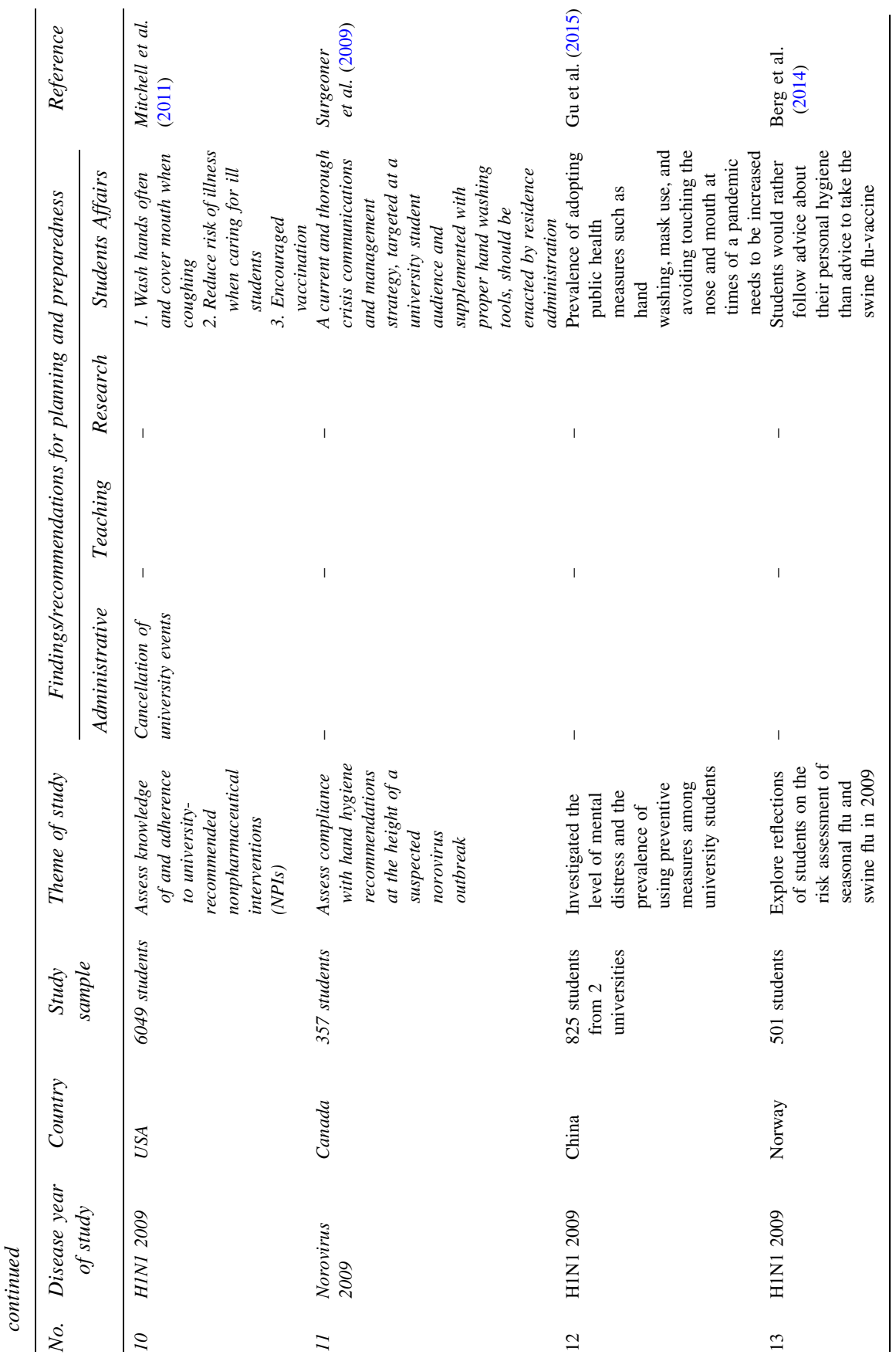

Higher Education Policy 202235 
Mohd Shahir Shamsir et al.

Development of a Haddon Matrix Framework

468

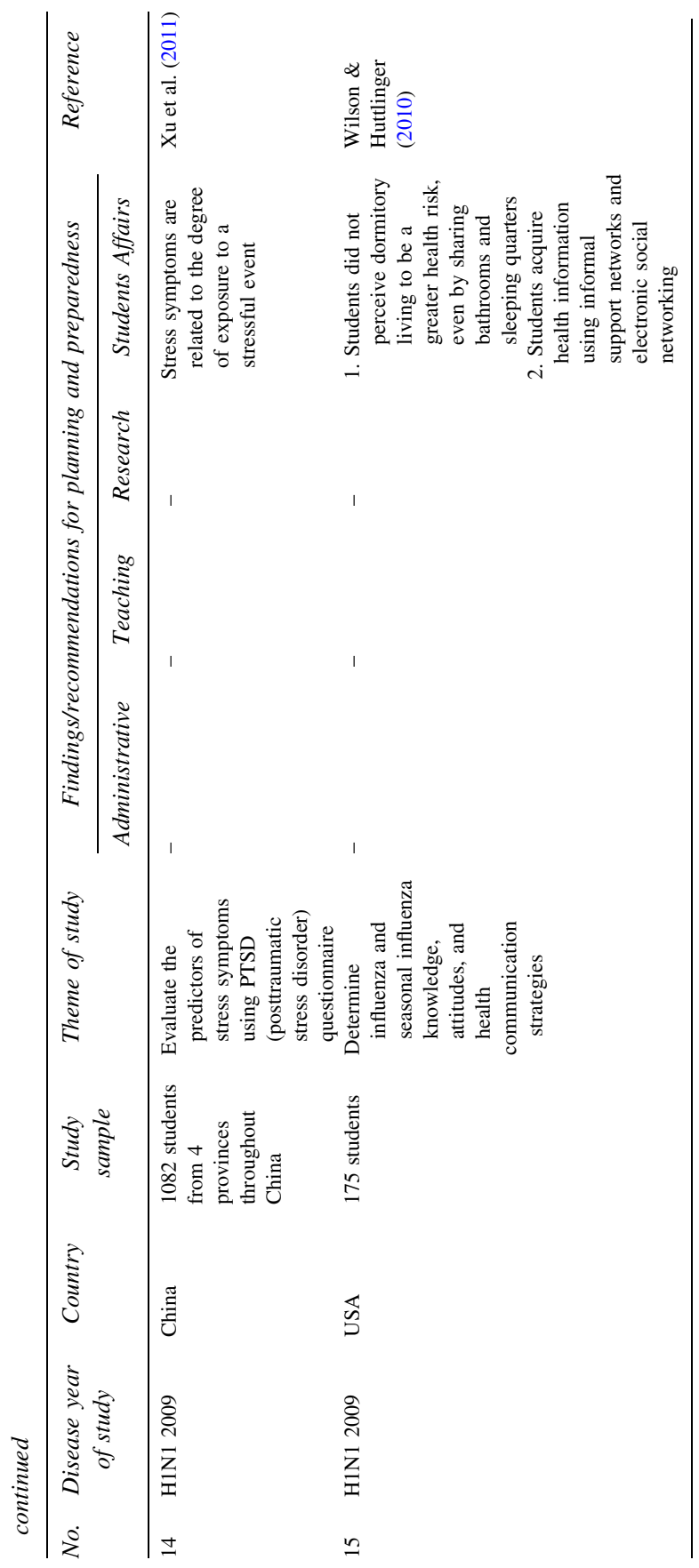

Higher Education Policy 202235 
Mohd Shahir Shamsir et al.

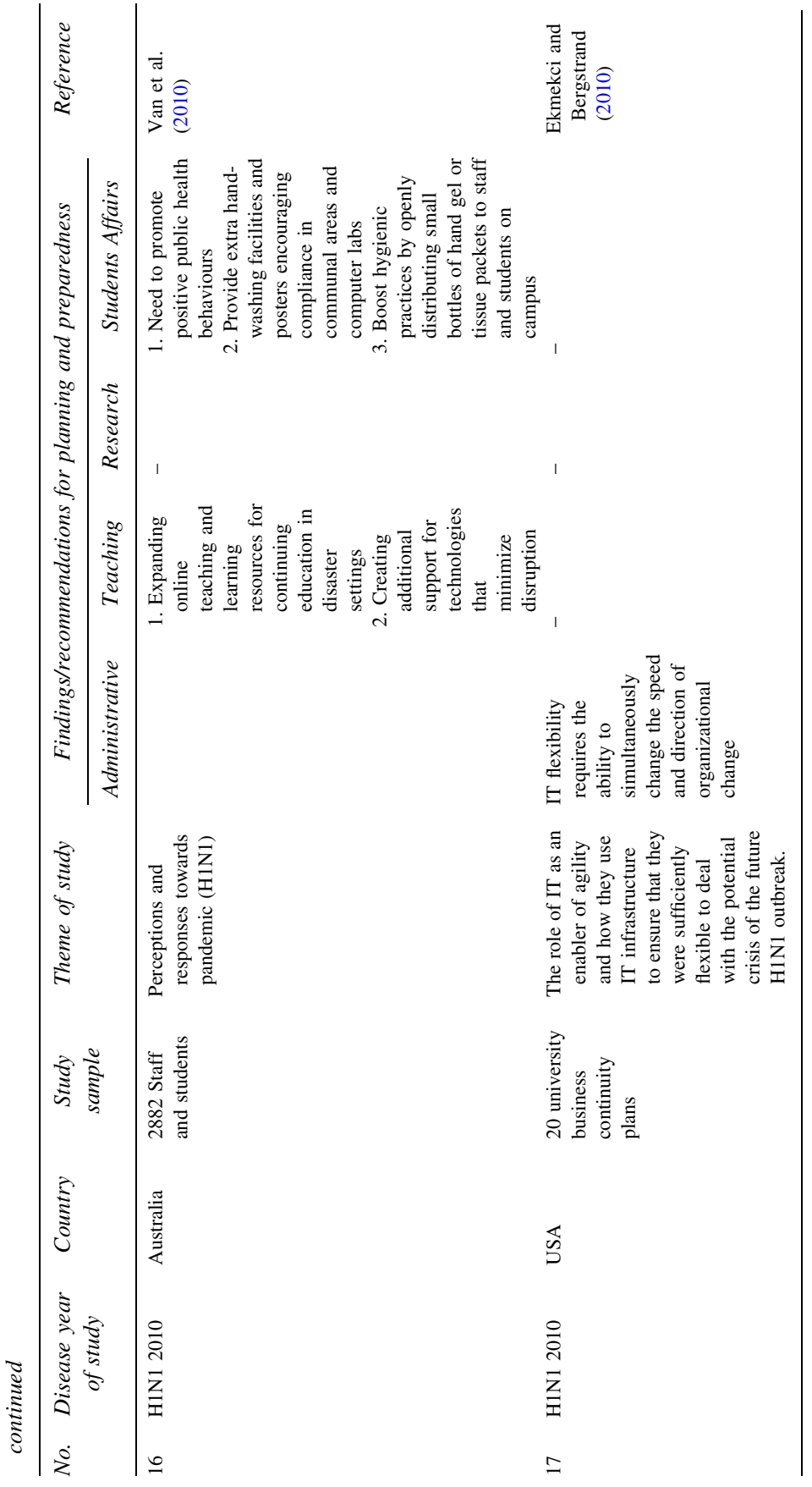


Mohd Shahir Shamsir et al.

Development of a Haddon Matrix Framework

470

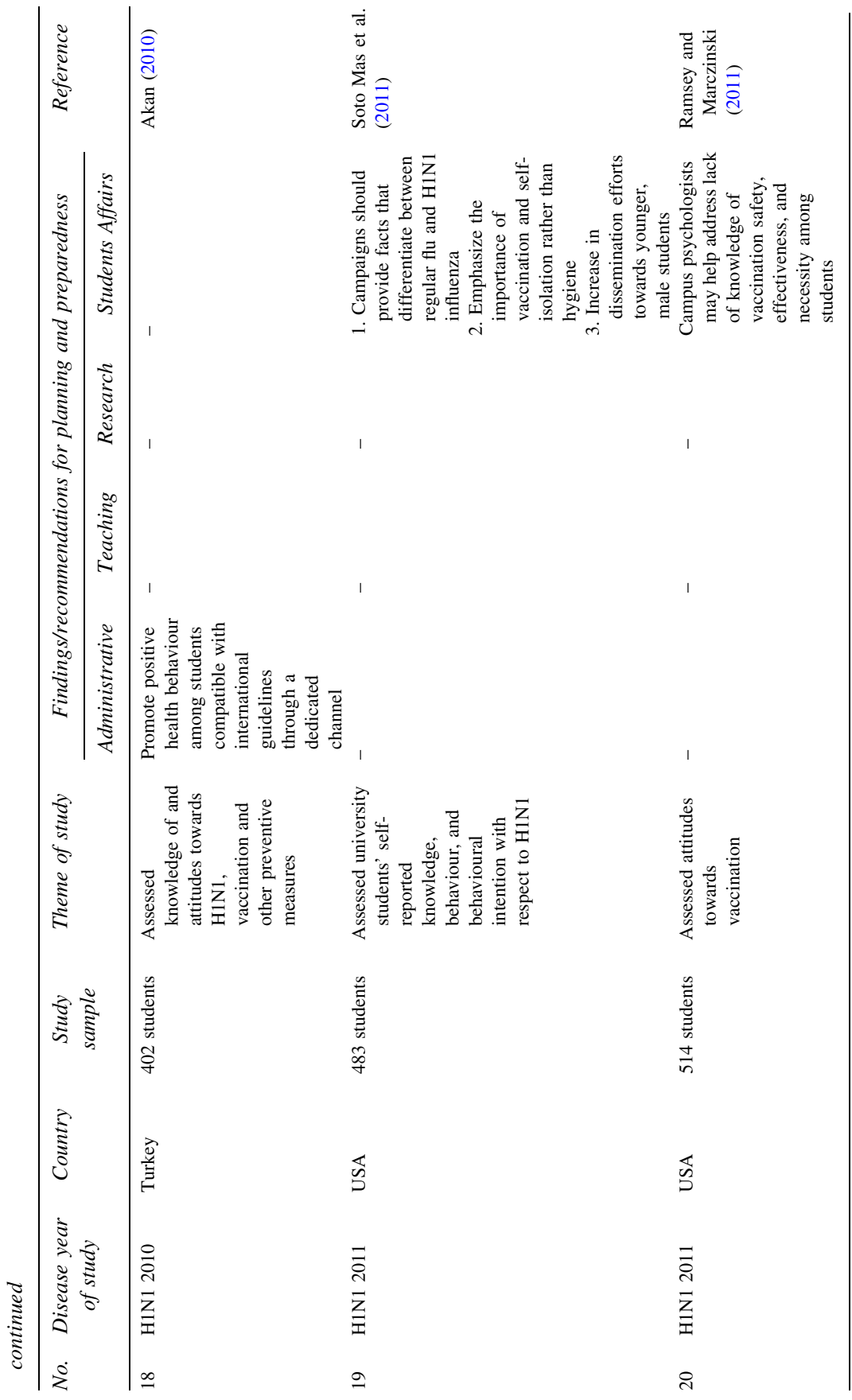

Higher Education Policy 202235 
Mohd Shahir Shamsir et al.

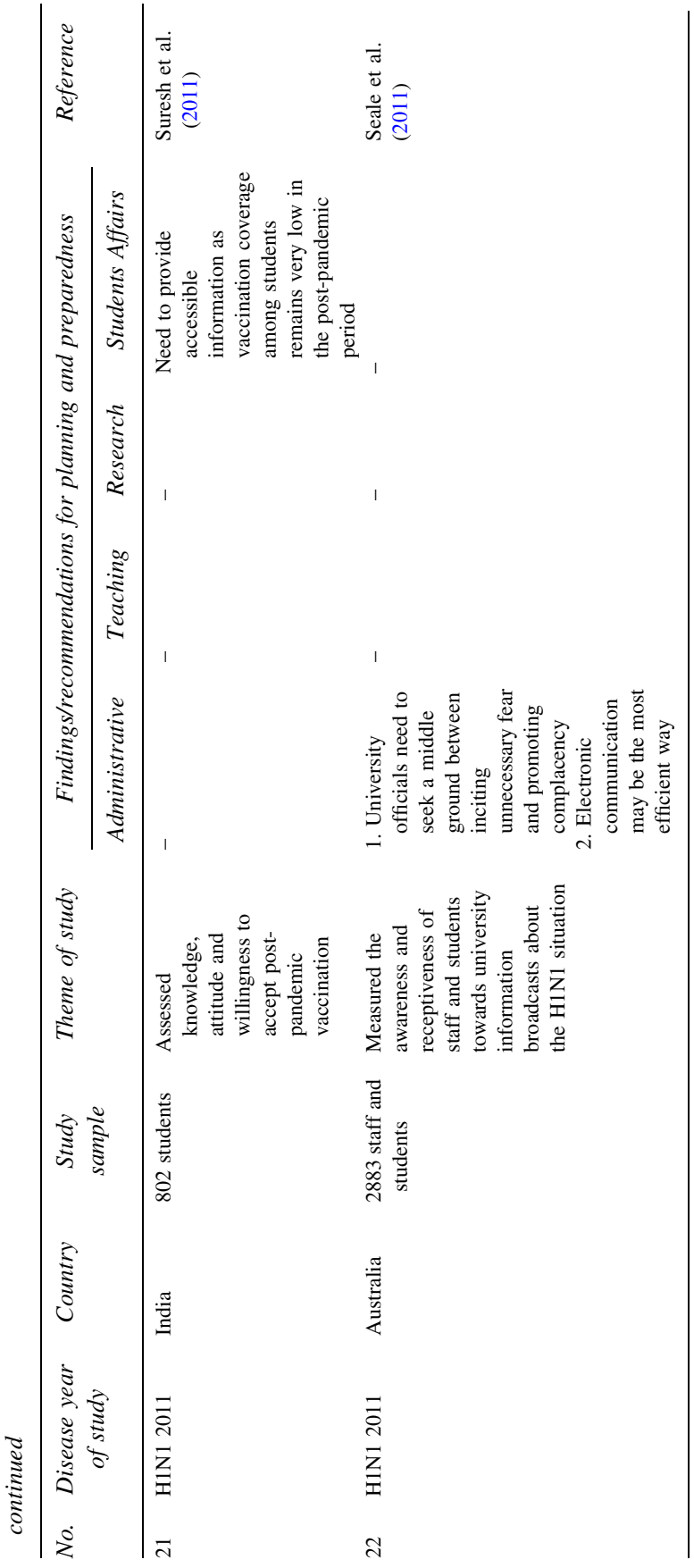




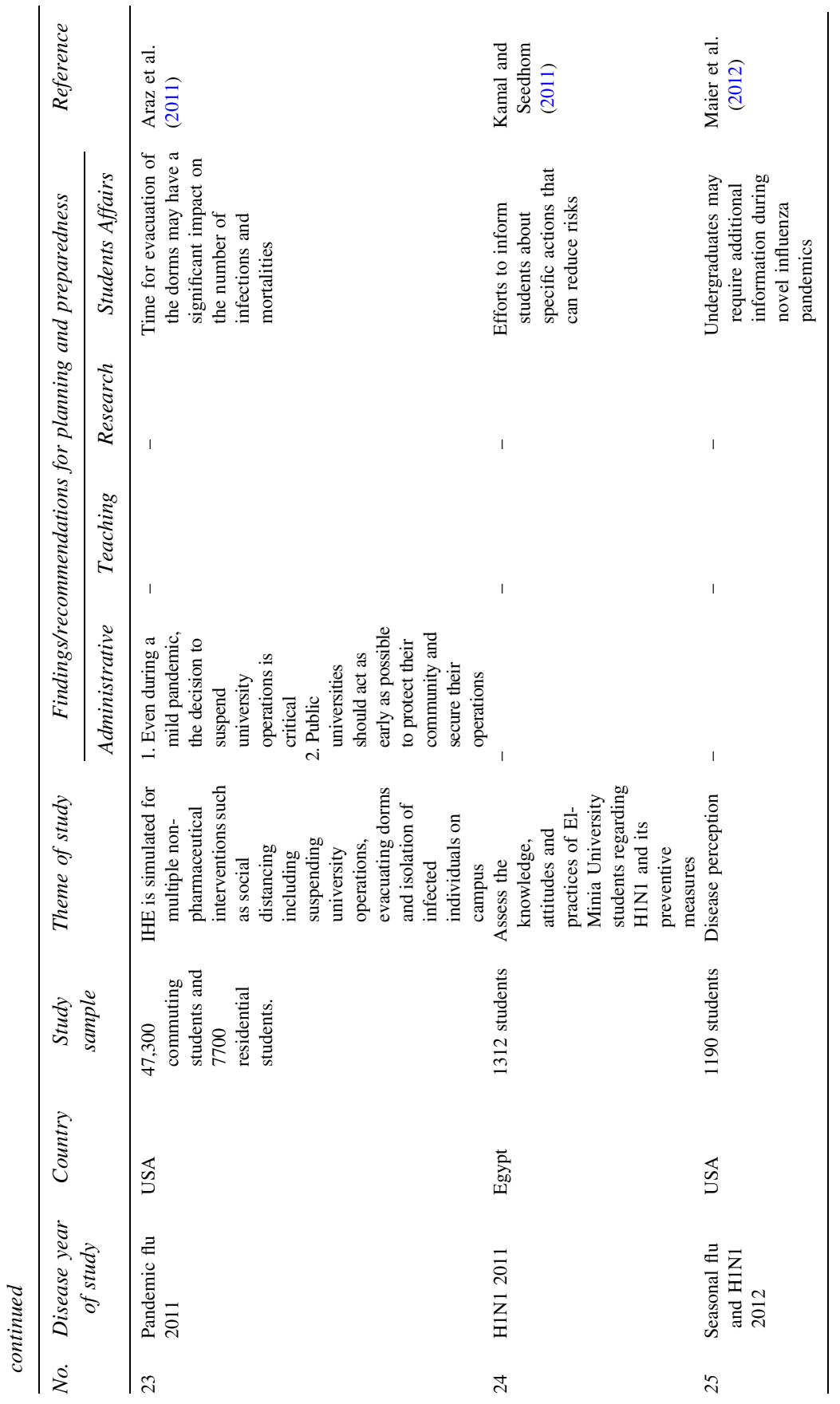


Mohd Shahir Shamsir et al. Development of a Haddon Matrix Framework
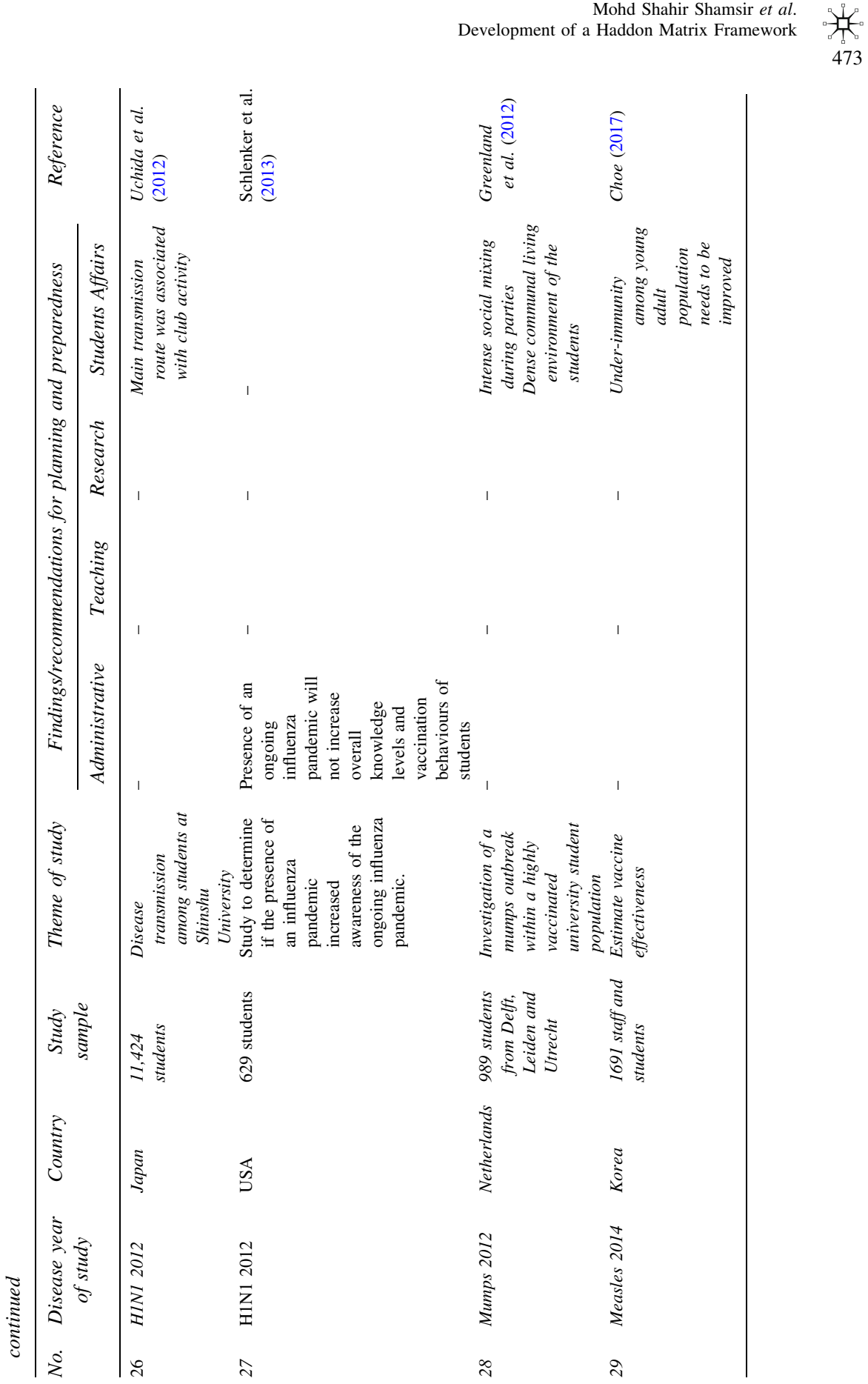

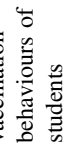
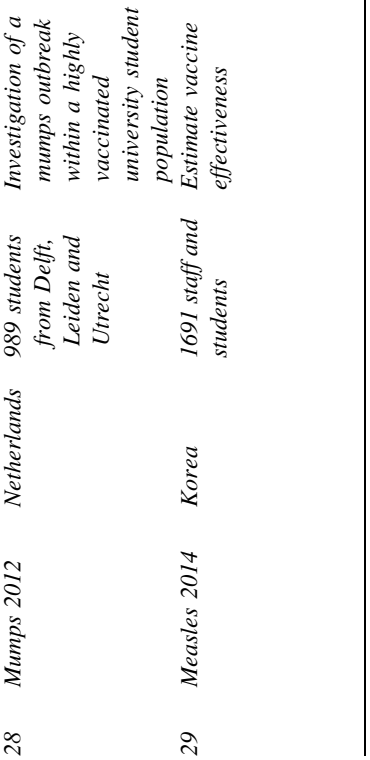

Higher Education Policy 202235 
Mohd Shahir Shamsir et al.

Development of a Haddon Matrix Framework

474

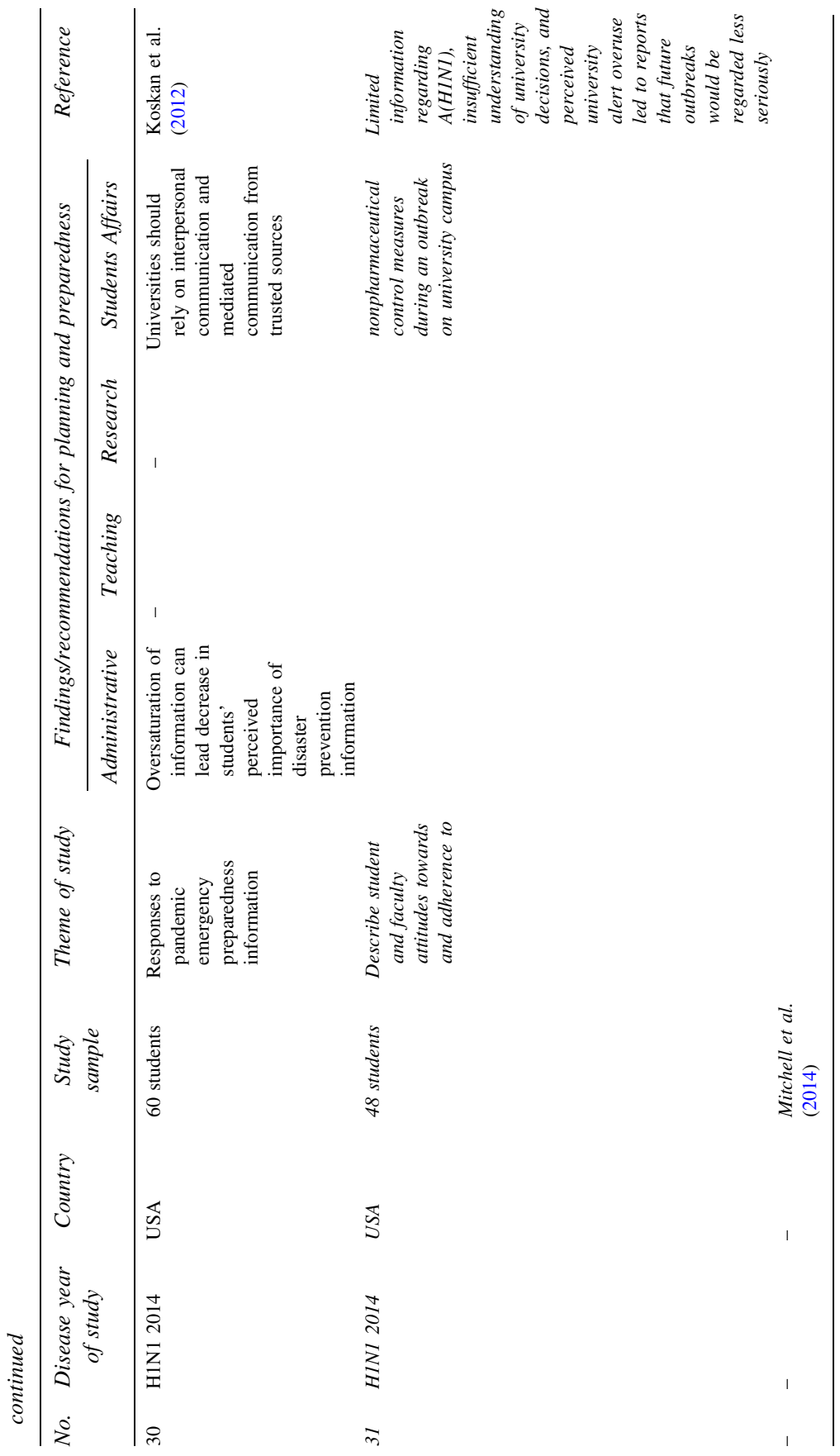

Higher Education Policy 202235 
Mohd Shahir Shamsir et al. Development of a Haddon Matrix Framework

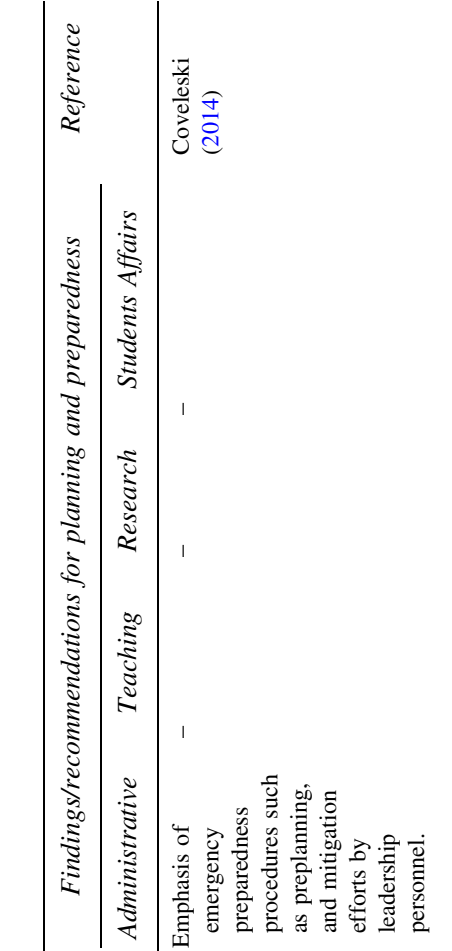

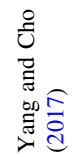
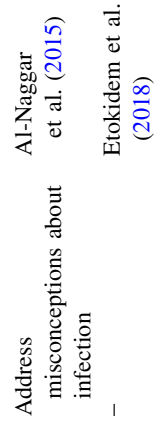

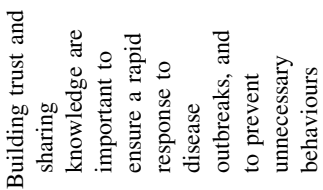

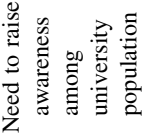

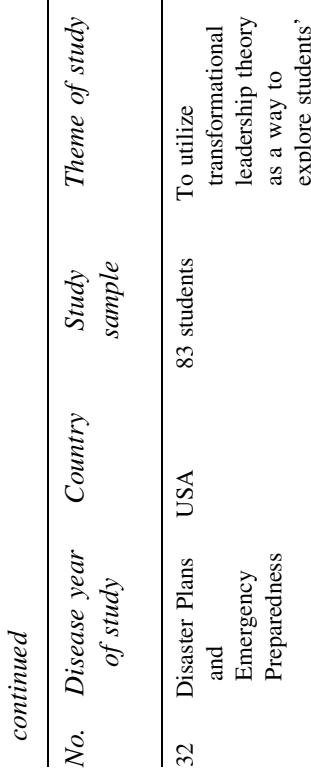

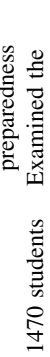

$\frac{\infty}{3} \Xi$ 휴

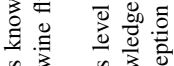

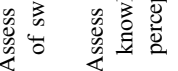

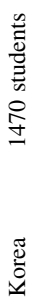

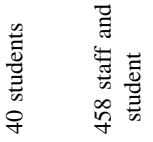

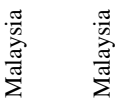

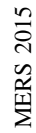

$\stackrel{\text { ก }}{\frac{\pi}{2}}$

省竞

$m$

m $m$

Higher Education Policy 202235 
Mohd Shahir Shamsir et al.

Development of a Haddon Matrix Framework

476

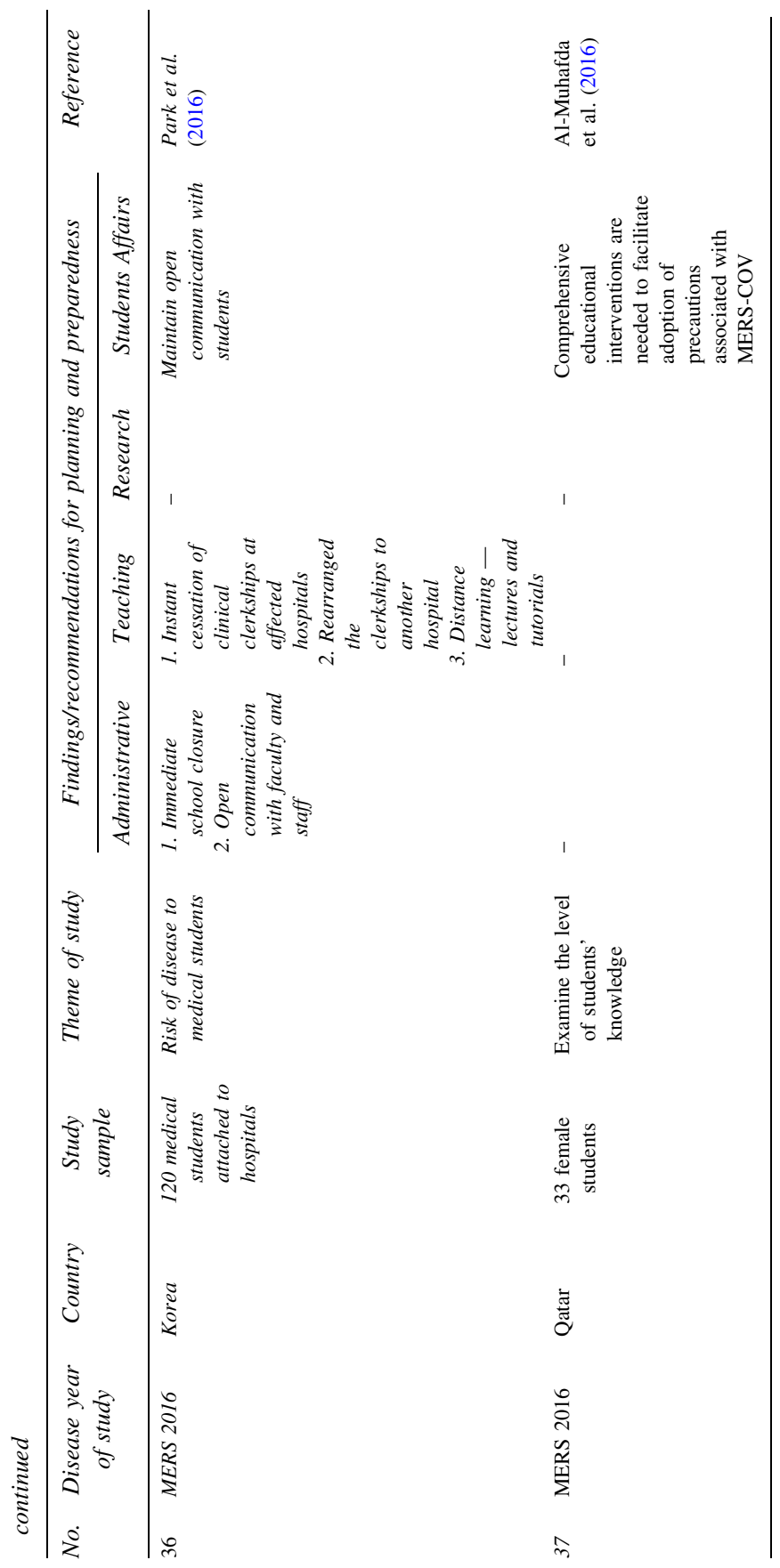

Higher Education Policy 202235 
Mohd Shahir Shamsir et al.
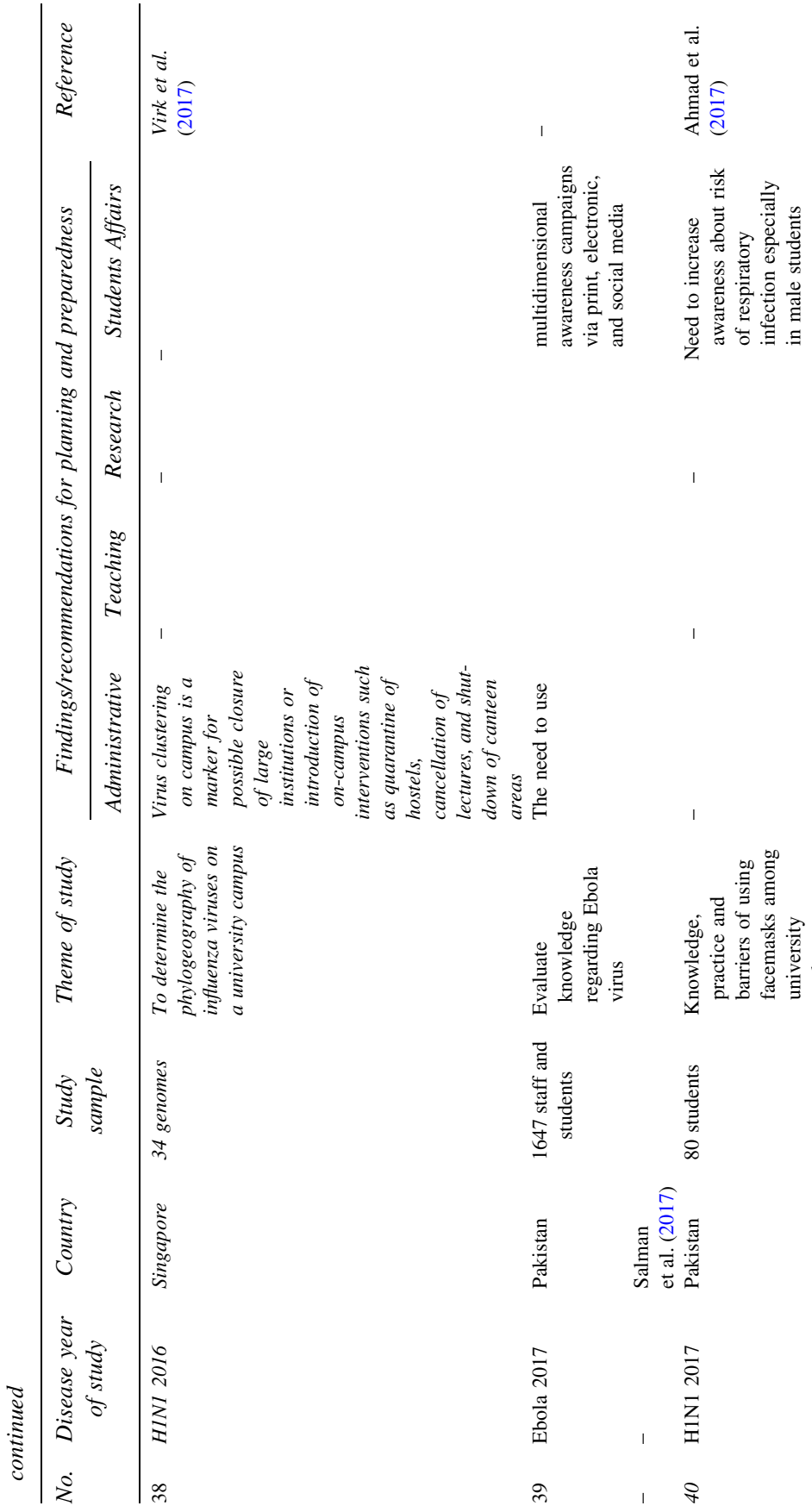

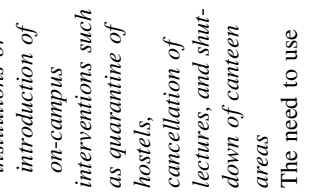

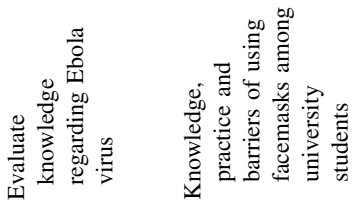

छ

焉总

0
$\frac{0}{0}$
$\overline{0}$
$\infty$
$\infty$

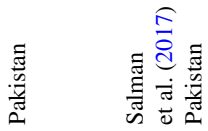

홍

$\frac{\pi}{8}$

จิ

II

ले

우 
Mohd Shahir Shamsir et al.

Development of a Haddon Matrix Framework

478

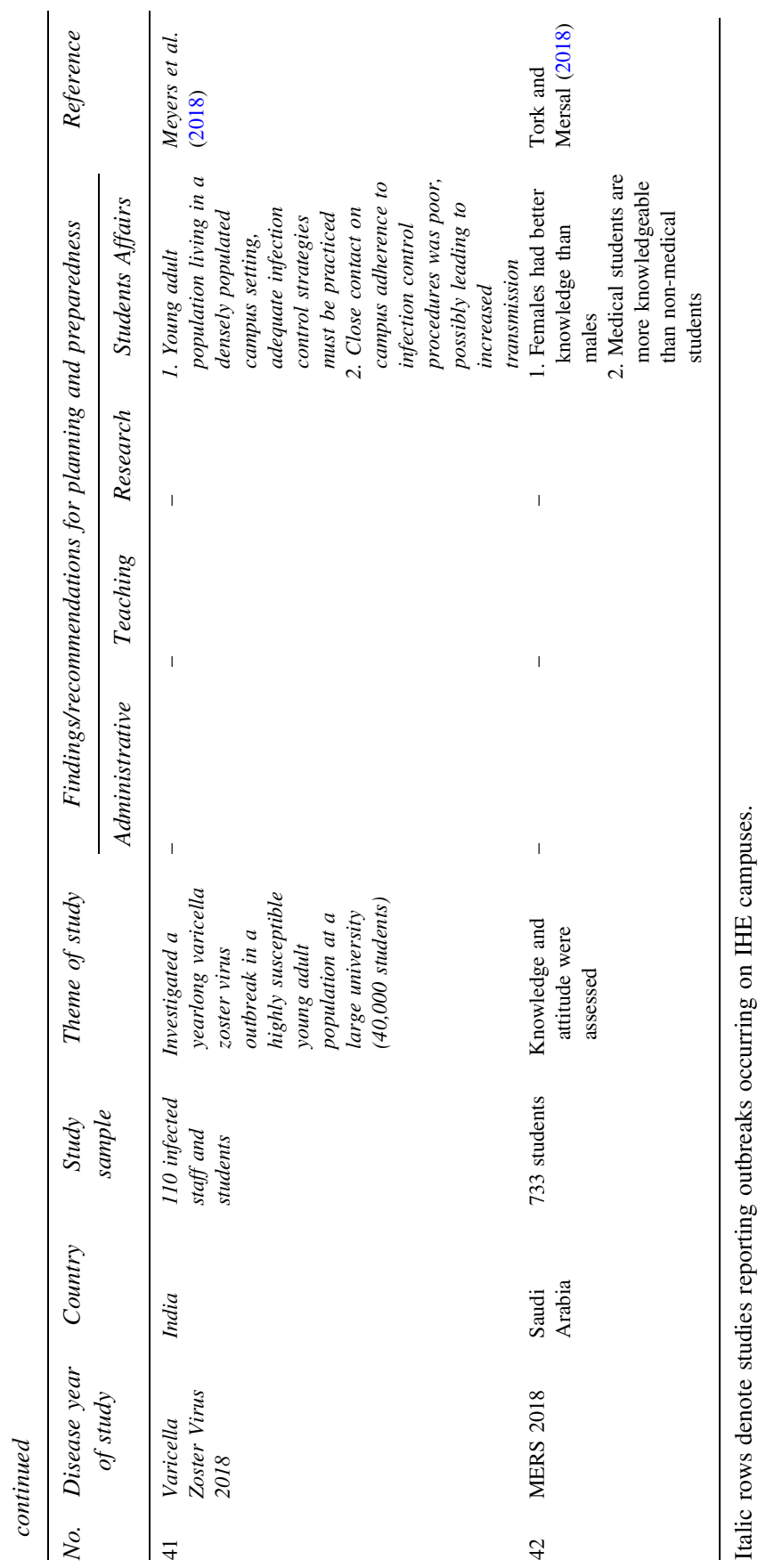

Higher Education Policy 202235 